Article

\title{
Karyotype Reorganization in Wheat-Rye Hybrids Obtained via Unreduced Gametes: Is There a Limit to the Chromosome Number in Triticale?
}

\author{
Olga G. Silkova ${ }^{1, *(1)}$, Yulia N. Ivanova ${ }^{1}$, Dina B. Loginova ${ }^{1}$, Lilia A. Solovey ${ }^{2}$, Elena A. Sycheva ${ }^{2}$ \\ and Nadezhda I. Dubovets ${ }^{2}$ (D) \\ 1 Institute of Cytology and Genetics, SB RAS, Lavrentiev av., 10, 630090 Novosibirsk, Russia; \\ kabanenko@bionet.nsc.ru (Y.N.I.); loginova.dina@gmail.com (D.B.L.) \\ 2 Institute of Genetics and Cytology, National Academy of Sciences of Belarus, Akademicheskaya 27, \\ 220072 Minsk, Belarus; lili_solovei@mail.ru (L.A.S.); E.Sycheva@igs.by (E.A.S.); n.i.dubovets@igc.by (N.I.D.) \\ * Correspondence: silkova@bionet.nsc.ru; Tel.: +7-(383)-363-49-80
}

Citation: Silkova, O.G.; Ivanova, Y.N.; Loginova, D.B.; Solovey, L.A.; Sycheva, E.A.; Dubovets, N.I. Karyotype Reorganization in Wheat-Rye Hybrids Obtained via Unreduced Gametes: Is There a Limit to the Chromosome Number in Triticale? Plants 2021, 10, 2052. https: / / doi.org/10.3390/ plants10102052

Academic Editor: Ekaterina D. Badaeva

Received: 10 August 2021 Accepted: 23 September 2021 Published: 29 September 2021

Publisher's Note: MDPI stays neutral with regard to jurisdictional claims in published maps and institutional affiliations.

Copyright: (c) 2021 by the authors. Licensee MDPI, Basel, Switzerland. This article is an open access article distributed under the terms and conditions of the Creative Commons Attribution (CC BY) license (https:/ / creativecommons.org/licenses/by/ $4.0 /)$.

\begin{abstract}
To date, few data have been accumulated on the contribution of meiotic restitution to the formation of Triticum aestivum hybrid karyotypes. In this study, based on FISH and C-banding, karyotype reorganization was observed in three groups of $F_{5}$ wheat-rye hybrids $1 R(1 \mathrm{~A}) \times R$. Aberrations, including aneuploidy, telocentrics, and Robertsonian translocations, were detected in all groups. Some of the Group 1 plants and all of the Group 2 plants only had a 4R4R pair (in addition to $1 R 1 R$ ), which was either added or substituted for its homeolog in ABD subgenomes. In about $82 \%$ of meiocytes, 4R4R formed bivalents, which indicates its competitiveness. The rest of the Group 1 plants had 2R and 7R chromosomes in addition to 1R1R. Group 3 retained all their rye chromosomes, with a small aneuploidy on the wheat chromosomes. A feature of the meiosis in the Group 3 plants was asynchronous cell division and omission of the second division. Diploid gametes did not form because of the significant disturbances during gametogenesis. As a result, the frequency of occurrence of the formed dyads was negatively correlated $(r=-0.73)$ with the seed sets. Thus, meiotic restitution in the $8 \mathrm{n}$ triticale does not contribute to fertility or increased ploidy in subsequent generations.
\end{abstract}

Keywords: wheat-rye amphidiploids; karyotype reorganization; FISH; C-banding; meiotic restitution; sterility

\section{Introduction}

Polyploidy plays a central role in plant genome evolution and in the formation of new species [1,2]. In addition to the ancient process of genome-wide duplication in all seed plants, in most plant species, including cultivated ones, two or more divergent genomes can merge via hybridization in a single nucleus [3]. The high heterozygosity of such allopolyploid species ensures the high genetic diversity of their progeny $[4,5]$.

The formation of polyploids is followed by their passing through a bottleneck of instability [6]. When two parental genomes join to form an allopolyploid genome, a "genomic shock" is experienced [7]. A multitude of evolutionary processes affects polyploid genomes, including rapid and substantial genome reorganization, transgressive gene expression alterations, gene fractionation, gene conversion, genome downsizing, and the sub- and neofunctionalization of duplicate genes [2,5,8-15]. Thus, new polyploid species, most of which have experienced several cycles of polyploidization [16], end up suffering a massive loss of "redundant" DNA and the restructuring of their chromosomes, as well as a repeated reduction in genome size [17]. Other changes in genomes at the chromosomal level involve duplications, deletions, fissions, fusions, translocations, and inversions of whole chromosomes, chromosome arms, or smaller segments [18].

The Poaceae family includes many typical allopolyploids. It has been found that the bread wheat subgenomes A, B, and D were originally derived from three diploid (2x; 
$2 n=14)$ species within the tribe Triticeae: Triticum urartu (AA), an extinct or undiscovered species in the lineage of Aegilops speltoides (BB), and Ae. tauschii (DD) [19,20]. The coadaptation of bread wheat subgenomes is evidenced by their structural and functional dissymmetry, manifesting itself as regional asymmetrical gene distribution and a lack of interaction at the transcriptional level of gene regulation, and by homologous exchange within genes [21-28].

The evolution of cereals has involved variations in chromosome structure and number. Recently, Murat et al. [29] and Pont et al. [21] suggested that Poaceae originated from an Ancestral Grass Karyotype (AGK), which existed 90 million years ago and contained $n=7$ protochromosomes. In the first step of paleoploidization - paleotetraploidization-a wholegenome duplication (WGD) produced $n=14$ chromosomes 65 million years ago. This was followed by reciprocal translocations, inversions, and telomeric/centromeric fusions to reach an $n=12$ chromosome intermediate [29]. Common wheat developed in the same way $[25,29]$. It is hypothesized that the Ancestral Triticeae Karyotype (ATK) originated from the 12 chromosomes of the AGK intermediate by means of six fusions and one fission $(n=7)$, followed by two rounds of neohexaploidization (involving progenitors/subgenomes A, $\mathrm{B}$, and D) that finally shaped the 21 modern bread wheat chromosomes [21]. Although gross chromosome homologies are conserved, structural changes involving chromosomes $4 \mathrm{~A}, 5 \mathrm{~A}$, and $7 \mathrm{~B}$ are apparently present in all hexaploid and tetraploid wheat in the Emmer group and 1G-4G-6 $A^{t}+3 A^{t}-4 A^{t}$ in the Timopheevii group [30-35]. Intra- and interspecific divergence, accompanied by species-specific chromosome rearrangements, have been found in two wheat groups, Emmer and Timopheevii [36]. Although all extant wild wheat have $x=7$, comparative cytogenetics highlights considerable chromosomal rearrangements within and among wild diploid and polyploid species [37-39].

Artificial polyploidization and remote hybridization are employed in breeding to increase crop yield [40]. Wild relatives are also used when raising allopolyploids in order to expand the genetic diversity of common wheat by the introgression of valuable alleles [41]. Triticale ( $\times$ Triticosecale Wittmack), the hybrid of wheat and rye, is an allopolyploid species that is evolutionarily younger than durum or common wheat. The earliest naturally emerging wheat-rye hybrids were discovered at the southeastern experimental agricultural station in Saratov in the late 1920s [42,43]. The plants showed intermediate traits and were described by G.K. Meister as a new botanical species, Triticum Secalotriticum saratoviense Meister [44]. The first stable amphiploid triticale (Triticosecale Wittmack) is attributed to Rimpau in 1888 [43]. Cytological examinations of the first triticales raised in Russia and Germany showed that their somatic chromosome number was 56 [44], which indicates the combination of four genomes, BBAADDRR. About $68 \%$ of repetitive and low-abundance DNA sequences are lost or modified when combined within a single nucleus [45-47]. Allopolyploidization in triticale can also be accompanied by rapid variations in retrotransposons, tandem repeats, regulatory units, coding sequences, and promoter sequences $[48,49]$. The rye parental genome is more prone to changes than the wheat one. After chromosome duplication, triticale genome reorganization occurs slowly, and most changes are confined to the first five generations [46]. The parental genotype affects genomic changes during allopolyploidization [49]. However, the expression of meiotic genes is highly resistant to changes induced by polyploidization [50]. The analysis of a large set of RNA-seq data showed that neither the level of synapsis, the ploidy level, nor the Ph1 locus affected overall meiotic transcription during the leptotene-zygotene transition stage in wheat-rye hybrids and doubled wheat-rye hybrids (newly synthesized triticale) [50].

The loss of DNA sequences alters the structures of rye and wheat chromosomes in the triticale chromosome set. This reorganization is also characterized by chromosome set instability, that is, the elimination of chromosomes or whole subgenomes [51-59].

Nearly all molecular and cytogenetical studies of genome reorganization have been conducted with triticale raised via colchicination. However, most natural polyploids arose sexually through the formation of unreduced gametes with somatic (2n) rather than 
haploid (n) chromosome numbers [3,60-62]. Polyploids may arise in one step via the fusion of two unreduced gametes or through a so-called triploid bridge. The triploid bridge mechanism seems to occur more often than the single-step pathway because of the low probability of the fusion of two unreduced gametes in natural populations [63]. Functional gametes in wheat-rye $\mathrm{F}_{1}$ hybrids are formed via meiotic restitution, in which there is no pairing of chromosomes, and univalents are divided into sister chromatids in the first meiosis after which the meiosis ends [64-66]. It was found that meiotic restitution is genetically controlled in wheat-rye hybrids [64-68] and inherited in durum wheat-rye hybrids $[54,66,67]$.

At present, little is known about the possibility of inheriting meiotic restitution, or about the contribution of meiotic restitution to the patterns of karyotype formation and the rate of meiotic stability restoration in common wheat-rye hybrids. Previously, we examined the chromosome sets, structures, and behavior in meiosis of the selected progenies (with good seed-setting ability) of $\mathrm{F}_{2-3}$ wheat-rye hybrids, obtained using the bread wheat $\mathrm{cv}$. Saratovskaya 29 and the wheat-rye substitution line $1 \operatorname{Rv}(1 \mathrm{~A})$, which determines meiotic restitution [64]. Karyotype analysis of the $\mathrm{F}_{2}$ Triticum aestivum L. cv. Saratovskaya $29 \times$ Secale cereale $\mathrm{L}$. var. Onochoyskaya $(\mathrm{S} 29 \times \mathrm{R})$ hybrid revealed 56 chromosomes; among them were 42 wheat chromosomes and 14 rye chromosomes [69]. The karyotype of the $\mathrm{F}_{2}$ $1 \operatorname{Rv}(1 \mathrm{~A}) \times \mathrm{R}$ hybrid contained 46 chromosomes, of which three pairs of rye chromosomes 1R1R4R4R2RL2RL, 1R1R replaced the chromosomes 1A1A, and 2RL2RL and 4R4R were added. In the $\mathrm{F}_{3}$ generation of $\mathrm{S} 29 \times \mathrm{R}$ hybrids, the octoploid number of chromosomes with aneuploidy of single rye and wheat chromosomes was preserved, while in the $1 \operatorname{Rv}(1 \mathrm{~A}) \times R$ hybrids, the number of chromosomes varied from 42 to 49 , but in most plants, $2 n=46$ was retained. The main meiotic disorders in hybrids $\mathrm{F}_{3} 1 \operatorname{Rv}(1 \mathrm{~A}) \times \mathrm{R}$ and $\mathrm{S} 29 \times \mathrm{R}$ was the presence of univalents in the first division and micronuclei in the second. Most disturbances are terminated by the fifth generation of allopolyploid hybrids [46,70]. Based on this, in the current work, we examined the chromosome sets, structures, and behaviors in meiosis of three groups of $F_{5}$ wheat-rye hybrids. Each group is the progeny of a single $F_{1}$ plant obtained by crossing the $1 \mathrm{Rv}(1 \mathrm{~A})$ common wheat disomic substitution line with the rye Secale cereale var. Onochoyskaya. The significant elimination of rye chromosomes was observed in the first two groups. The chromosome numbers in Group 3 varied from 52 to 56. All rye chromosomes were preserved there, but the wheat chromosomes showed insignificant aneuploidy. Our observations suggest that genome reorganization is not finished in any group of $\mathrm{F}_{5}$ descendants. The meiosis in the hybrids was unstable. Specific features of meiosis in the plants of the third group included asynchronous cell division and the omission of the second division, followed by significant disturbances during mitosis in gametogenesis. In the other two groups, the second division of meiosis took place. Therefore, meiotic restitution in $8 \mathrm{n}$ triticale was inherited but did not contribute to increases in ploidy in subsequent generations.

\section{Materials and Methods}

Three groups of F5 plants were obtained by crossing the $1 \operatorname{Rv}(1 \mathrm{~A})$ disomic wheat-rye substitution line $(2 n=42)$ (T. aestivum L. cv. Saratovskaya 29/S. cereale L. cv. Vyatka) [71] with spring rye Secale cereale L. var. Onokhoiskaya was investigated. Rye Onokhoiskaya tolerates spring frosts and May-June drought and is resistant to diseases and pests. The $1 \operatorname{Rv}(1 \mathrm{~A})$ disomic wheat-rye substitution line is cytogenetically stable [71] and determines meiotic restitution [64]. The partially fertile $\mathrm{F}_{1}$ hybrids $4-3,4-7$, and 73-1 arose from unreduced gametes [64].

Six seeds were set in the $F_{1}$ 4-3 plant, and they produced only 2 fertile $F_{2}$ plants (6-1 and 6-2), which were taken for further study (Table S1, Figure 1). As the seeds of each plant were sown separately, starting from $\mathrm{F}_{1}$, their progeny was designated as lines. In the $\mathrm{F}_{3}$ of plant 6-1 (subgroup 1a), only 1 plant (22-4) was fertile, while 4 high-yield plants were obtained in $\mathrm{F}_{4}$. One low-yield plant (23-8) and 2 plants with different numbers of grains (23-10 and 23-13) were chosen from the $\mathrm{F}_{3}$ progeny of plant 6-2 (subgroup $1 \mathrm{~b}$ ). A 
total of 12 high-yield plants were chosen from $\mathrm{F}_{4}$ in subgroup $1 \mathrm{~b}$ (Figure 1). As a result, the chromosome sets were analyzed in the $\mathrm{F}_{5}$ plants that originated from $16 \mathrm{~F}_{4}$ plants. Some of the grains of one plant were sown in the greenhouse; karyotypes were analyzed in vegetative plants using FISH. Other grains from the same plant were transferred for karyotype analysis using C-banding.

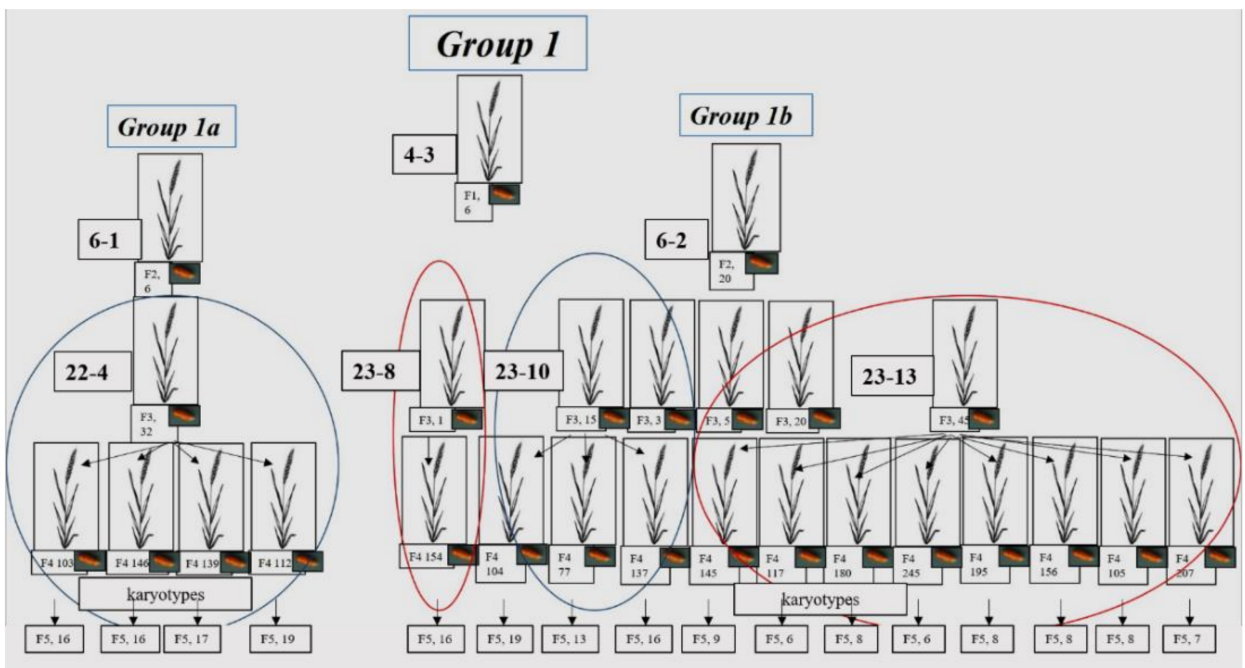

Figure 1. Development of wheat-rye hybrids of Group 1. The scheme shows individual plants from the $\mathrm{F}_{1}-\mathrm{F}_{4}$ generations, and the number of seeds in these plants. For the $\mathrm{F}_{5}$ generation, the number of plants analyzed for karyotype is shown.

Five seeds were set in plant $\mathrm{F}_{1}$ 4-7 (Group 2). They yielded 5 plants, and 3 high-yield plants were chosen for further crosses. To obtain generation $\mathrm{F}_{3}, 36$ seeds were taken from each plant, and 5 high-yield plants from these 36 were selected to obtain $\mathrm{F}_{4}$ (Table S1, Figure 2). Finally, chromosome sets were analyzed in $\mathrm{F}_{5}$ plants originating from $15 \mathrm{~F}_{4}$ plants via C-banding.

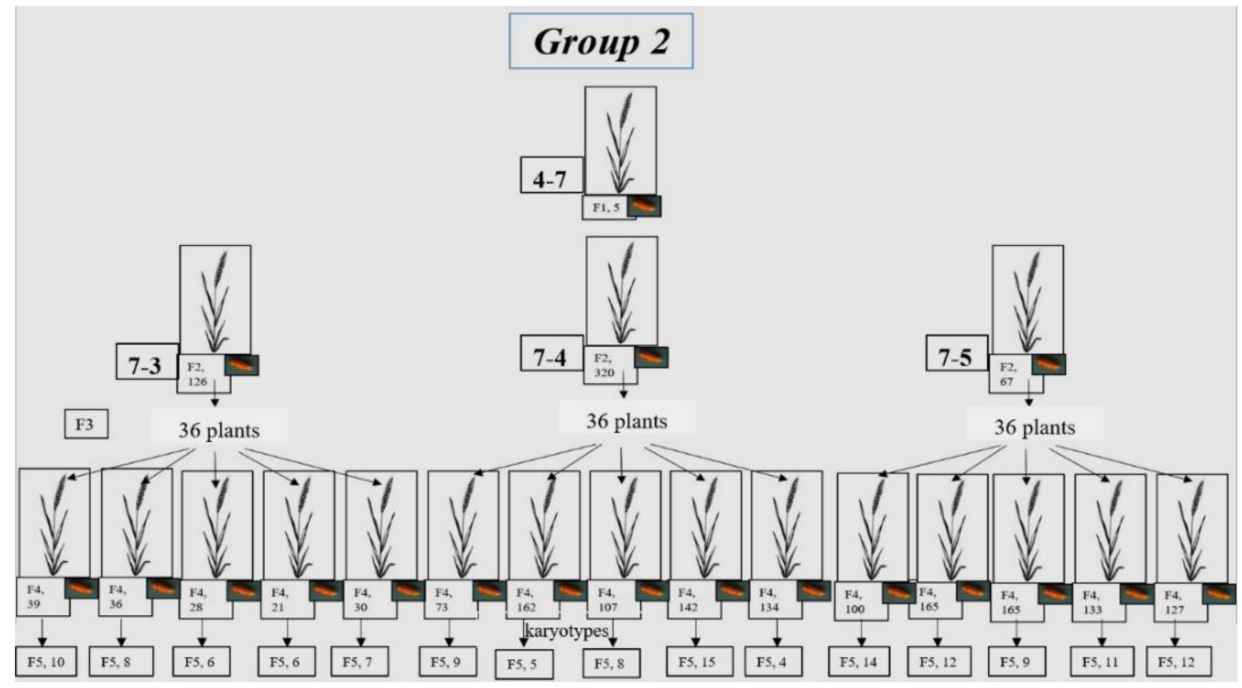

Figure 2. Development of wheat-rye hybrids of Group 2. The scheme shows individual plants of the $\mathrm{F}_{1}-\mathrm{F}_{4}$ generations, and the number of seeds in these plants. In the $\mathrm{F}_{5}$ generation, the number of plants analyzed for karyotype is shown.

One seed was set in plant $F_{1}$ 73-1 (Table S1, Group 3), and 35 seeds in $F_{2}(26-1)$. Generation $\mathrm{F}_{3}$ plants were grown from these seeds, only 8 of which were fertile (Figure 3 ). The 3 plants with the most seeds were selected. In total, 4 plants with the most seeds were 
chosen from $\mathrm{F}_{4}$. Some of the grains of each of the 4 plants were sown in the greenhouse; karyotypes were analyzed in the vegetative plants using FISH. Other grains from the same plants were transferred for karyotype analysis using C-banding.

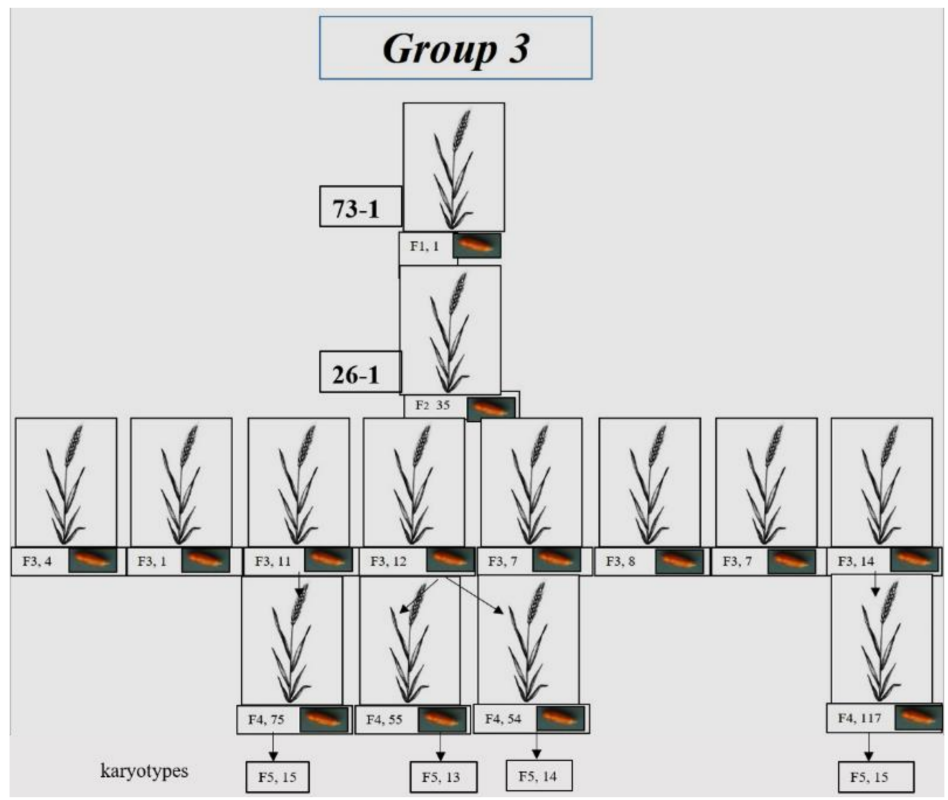

Figure 3. Development of wheat-rye hybrids of Group 3. The scheme shows individual plants of the $\mathrm{F}_{1}-\mathrm{F}_{4}$ generations and the number of seeds in these plants. The number of plants in the $\mathrm{F}_{5}$ generation in which the karyotype was analyzed is shown.

$\mathrm{F}_{5}$ hybrids were grown in a greenhouse under a $24 / 18{ }^{\circ} \mathrm{C}$ day/night temperature regime and a $16 / 8 \mathrm{~h}$ day/night schedule.

\subsection{Routine Meiosis Analysis}

To analyze meiotic division, young spikes were fixed in ethyl alcohol-acetic acid 3:1 and stored at $4{ }^{\circ} \mathrm{C}$. Pollen mother cells (PMCs) were stained with and squashed in $3 \%$ acetocarmine. All of the anthers with PMCs at metaphase I-anaphase I and anaphase II-telophase II, and with separate microspores, were examined (Table 1). Each anther was analyzed individually, assaying all PMCs in each anther.

Table 1. Material analyzed.

\begin{tabular}{|c|c|c|c|c|c|c|c|c|}
\hline \multirow{3}{*}{ Hybrid $F_{2}$} & \multirow{3}{*}{ Hybrid $F_{3}$} & \multirow{3}{*}{ Hybrid $\mathrm{F}_{4}$} & \multicolumn{6}{|c|}{ Hybrids $F_{5}$} \\
\hline & & & \multicolumn{3}{|c|}{ Routine Analysis } & \multicolumn{3}{|c|}{ FISH } \\
\hline & & & Plants & Anthers & Meiocytes+ Microspores & Plants & Anthers & Meiocytes \\
\hline \multirow{4}{*}{ 6-1 (subgroup 1a) } & \multirow{4}{*}{$22-4$} & $72-3$ & 7 & 15 & 1419 & 3 & 7 & 228 \\
\hline & & $72-4$ & 4 & 11 & 826 & 5 & 10 & 489 \\
\hline & & $72-11$ & 4 & 17 & 1851 & 2 & 7 & 315 \\
\hline & & $72-12$ & 6 & 23 & 2934 & 6 & 10 & 684 \\
\hline \multirow{4}{*}{ 6-2 (subgroup 1b) } & $23-8$ & $76-1$ & 11 & 27 & 3304 & - & - & - \\
\hline & \multirow{3}{*}{$23-10$} & $77-1$ & 4 & 11 & 1007 & - & - & - \\
\hline & & $77-4$ & 6 & 16 & 1482 & - & - & - \\
\hline & & $77-8$ & 6 & 12 & 961 & - & - & - \\
\hline \multirow{4}{*}{ 73-1 (group 3) } & $41-7$ & $87-1$ & 9 & 43 & 3215 & 3 & 7 & 112 \\
\hline & $41-16$ & $88-1$ & 9 & 47 & 2862 & 2 & 5 & 72 \\
\hline & & $88-2$ & 6 & 34 & 3117 & - & - & - \\
\hline & $41-22$ & $89-6$ & 8 & 41 & 3096 & 3 & 6 & 82 \\
\hline
\end{tabular}




\subsection{Giemsa C-banding}

C-banding was carried out as in [72]. The slides were examined under an Amplival microscope (Carl Zeiss Jena). Images were recorded with a LeicaDS300 camera (Leica Microsystems) and processed using the Adobe Photoshop CC2017 software.

Chromosomes were identified using a generalized species idiogram [73,74].

\subsection{Fluorescence In Situ Hybridization (FISH)}

The mitotic and meiotic slides used for FISH were prepared as in [64]. Meiocytes were analyzed at metaphase I (MI) (Table 1). The following probes were used: Aegilops tauschii pAet6-09, specific to centromeric repeats on chromosomes of rice, wheat, rye, and barley [75,76]; pAWRc, specific to the rye chromosome centromeric repeat [77]; rye genomic DNA. The samples of plasmid DNA containing the corresponding repeats were kindly provided by Dr. A. Lukaszewski (University of California, United States). Centromerespecific probe pAet6-09 was labeled with biotin-16-dUTP and pAWRc with digoxigenin-11dUTP via polymerase chain reaction (PCR). Total rye DNA was labeled by nick translation using digoxigenin-11-dUTP. The probes were used separately or in combination (rye DNA/centromere and pAet6-09/ pAWRc) and were mixed with blocking (sonicated) wheat DNA. Biotinylated probes were detected using avidin conjugated to fluorescein (Fluorescein Avidin D, Vector Laboratories, No. A-2001), and the hybridization signal was amplified using fluorescein anti-avidin (Fluorescein Anti-Avidin D, Vector Laboratories, No. SP-2040). Digoxigenin-labeled probes were detected using anti-digoxigenin antibodies conjugated with rhodamine (Anti-digoxigenin-rhodamine, Fab fragments, Sigma-Aldrich, no. 11207750910 ROCHE). Chromatin was stained with $1 \mathrm{mg} / \mathrm{mL}$ DAPI (4',6-diamidino-2phenylindole) in Vectashield anti-fade solution (Vector Laboratories).

All slides were examined under an Axio Imager M1 (Carl Zeiss) microscope. Images were recorded with a ProgRes MF camera (Meta Systems, Jenoptic) and processed using the Adobe Photoshop CS2 software.

\subsection{Statistical Analysis}

Associations between 2 traits (the number of grains and the percentage of micronuclei at telophase II, the number of grains, and the percentage of dyads at telophase II) were determined using the Pearson correlation coefficient (Microsoft Excel program). The significance of the correlation was determined using the Student's $t$-test and the Chaddock scale (Table 2).

Table 2. Criteria for interpreting the strength of the relationship between two variables.

\begin{tabular}{cc}
\hline Correlation Coefficient & Interpretation \\
\hline 0.90 to $1.00(-0.90$ to -1.00$)$ & $\begin{array}{c}\text { Very high positive (negative) correlations, very } \\
\text { dependable associations }\end{array}$ \\
\hline 0.70 to $0.90(-0.70$ to -0.90$)$ & $\begin{array}{c}\text { High positive (negative) correlations, marked } \\
\text { associations }\end{array}$ \\
\hline 0.50 to $0.70(-0.50$ to -0.70$)$ & $\begin{array}{c}\text { Moderate positive (negative) correlations, } \\
\text { substantial associations }\end{array}$ \\
\hline 0.30 to $0.50(-0.30$ to -0.50$)$ & $\begin{array}{c}\text { Low positive (negative) correlations, defined } \\
\text { but small associations }\end{array}$ \\
\hline 0 to $0.30(0$ to -0.30$)$ & Negligible correlations \\
\hline
\end{tabular}

\section{Results}

3.1. Karyotyping

\subsubsection{Group 1}

The FISH and C-banding data indicate that the chromosome sets of the $\mathrm{F}_{5}$ descendants of two sister lines (subgroups 1a and 1b) differ. Plants with $2 n=44$ and $2 n=43$ (47.05 
and $36.76 \%$, respectively) were predominant in subgroup 1a (Figure 4 ). The numbers of rye chromosomes varied from three to six, and most sets $(79.4 \%)$ displayed four rye chromosomes, namely, disomic $1 \mathrm{R}$ and $4 \mathrm{R}$ (Figure 5). Chromosome $1 \mathrm{R}$ was trisomic or tetrasomic in sets with six rye chromosomes. Wheat chromosomes were mostly present in the disomic state, and chromosomes 3B, 4A, 4D, 5D, and 7D were monosomic in sets one, two, one, one, and one, respectively. The rye chromosome $1 \mathrm{R}$ always replaced wheat $1 \mathrm{~A}$. Chromosome $4 \mathrm{R}$ replaced chromosome $4 \mathrm{D}$ in one plant and $4 \mathrm{~A}$ in two. In other plants, this chromosome was added to the wheat chromosomes.

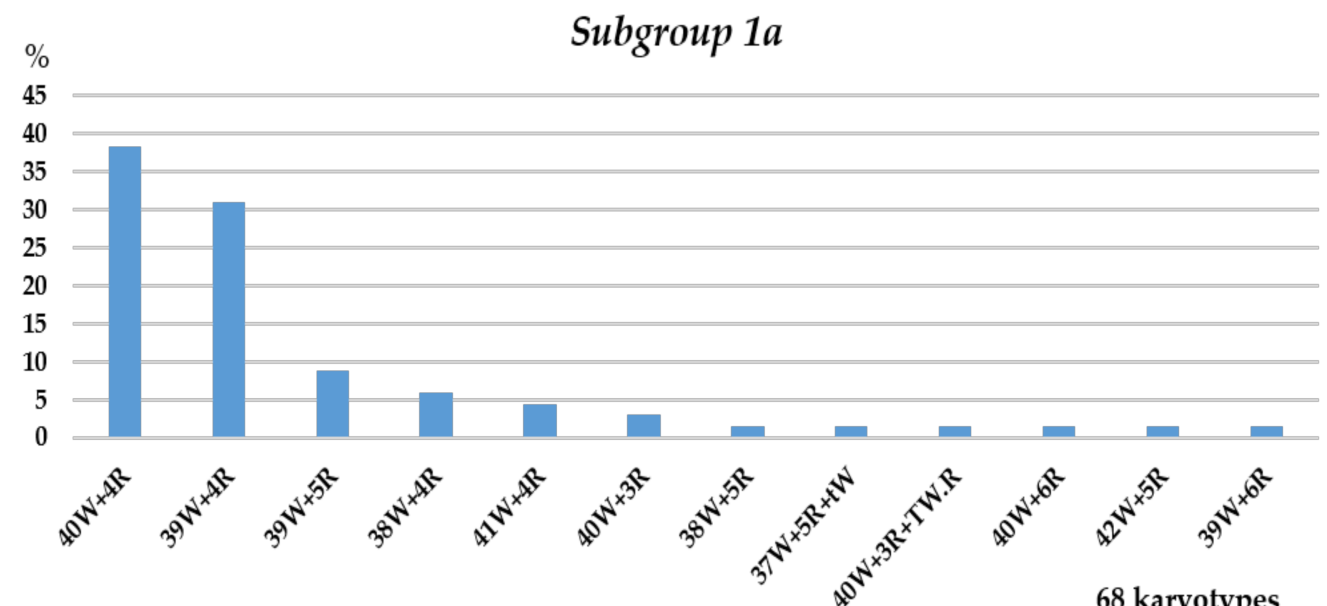

68 karyotypes

Figure 4. Frequencies of different chromosome sets in the plant karyotypes of subgroup 1a, 22-4 plant progeny. Designations: $T$, Robertsonian translocation; $t$, telocentric; $W$, wheat chromosomes; $\mathrm{R}$, rye chromosomes.

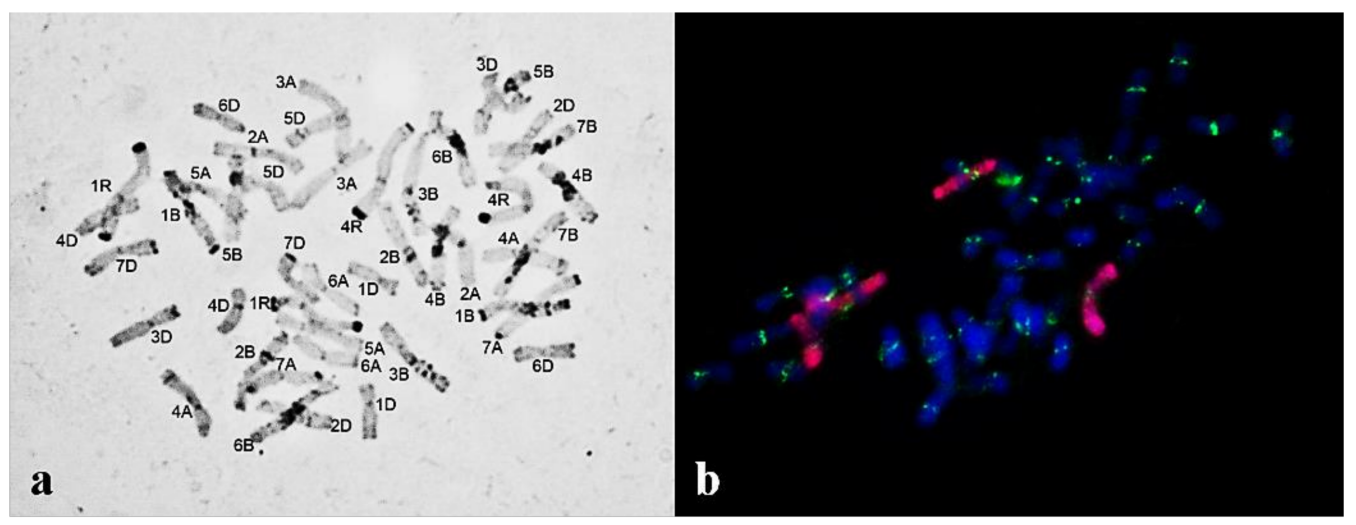

Figure 5. Chromosome sets of plants of subgroup 1a: (a) $2 n=44,1 \mathrm{R}(1 \mathrm{~A})$ substitution, $4 \mathrm{R} 4 \mathrm{R}$ added (C-banding); (b) $2 n=44$, four rye chromosomes (GISH; rye chromosomes are labeled red and centromeres, green).

Subgroup $1 b$ included chromosome sets of $F_{5}$ plants obtained from three $F_{3}$ plants (Figures 1 and 6). This subgroup was distinguished by the presence of the three rye chromosomes $1 R, 2 R$, and $7 R$, while $4 R$ was absent. Chromosome $1 R$ was found in the disomic state in all plants, and it replaced wheat chromosome 1A. The chromosomes $2 \mathrm{R}$ and $7 \mathrm{R}$ were monosomic. This group was also marked by wheat-rye Robertsonian translocations and wheat and rye telocentric chromosomes (Figure 6). 


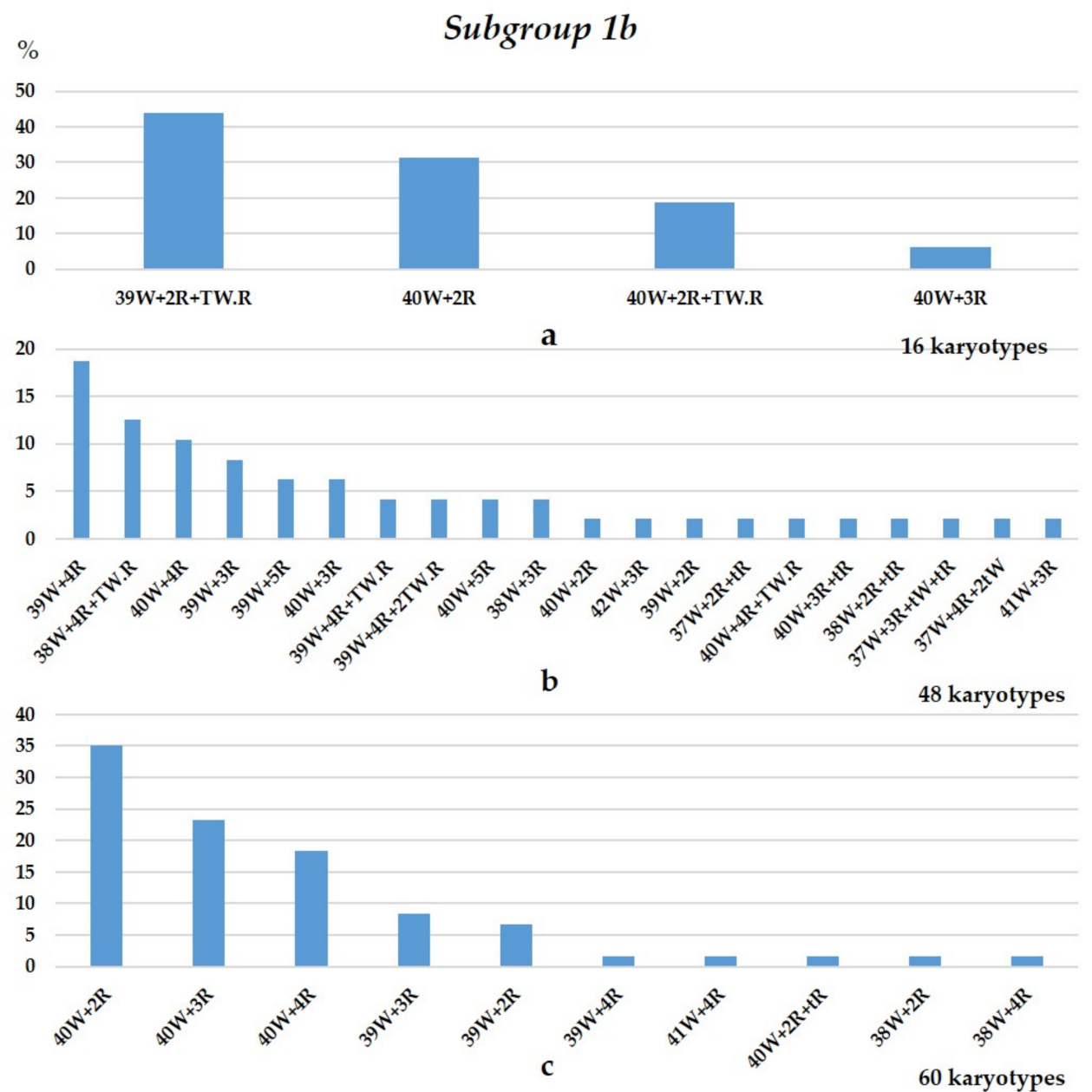

Figure 6. Frequencies of different chromosome sets in the plant karyotypes of subgroup 1b: (a) 23-8 plant progeny; (b) 23-10 progeny; (c) 23-13 progeny. Designations follow Figure 4.

Chromosome sets in the progeny of plant 23-8 (Figure 7a) formed three major groups: 39W+1R1R+T1BL.1RL (43.75\%) (Figure 6a), 40W+1R1R (31.25\%), and 40W+2R+T1BL.1RL $(18.75 \%)$. The three major groups in the progeny of $23-13$ were $40 \mathrm{~W}+1 \mathrm{R} 1 \mathrm{R}(35 \%)$, $40 \mathrm{~W}+1 \mathrm{R} 1 \mathrm{R}+2 \mathrm{R}(23.33 \%)$, and $40 \mathrm{~W}+1 \mathrm{R} 1 \mathrm{R}+2 \mathrm{R}+7 \mathrm{R}(18.33 \%)$ (Figure 6c). Wheat chromosomes were in the disomic state with few exceptions (3A, 2D, and $4 \mathrm{~B}$ were monosomic).

A different pattern was observed in the progeny of plant 23-10. Their chromosome sets were more diverse: a total of 20 different sets were found (Figure $6 \mathrm{~b}$ ). The most frequent chromosome sets were 39W+1R1R+2R+7R (18.75\%), 38W+1R1R+2R2R+T2RL.W (12.5\%), and $40 W+1 R 1 R+2 R+7 R(10.41 \%)$. The numbers of rye chromosomes varied from two to five. The $40 \mathrm{~W}+1 \mathrm{R} 1 \mathrm{R}$ set was found in only one plant. Sets with wheat and rye telocentrics and with Robertsonian translocations were found in $33.33 \%$ of plants. The translocated chromosomes had hybrid centromeres because the centromeric repeats pAet6-09 and pAWRc did not overlap (Figure 8). 


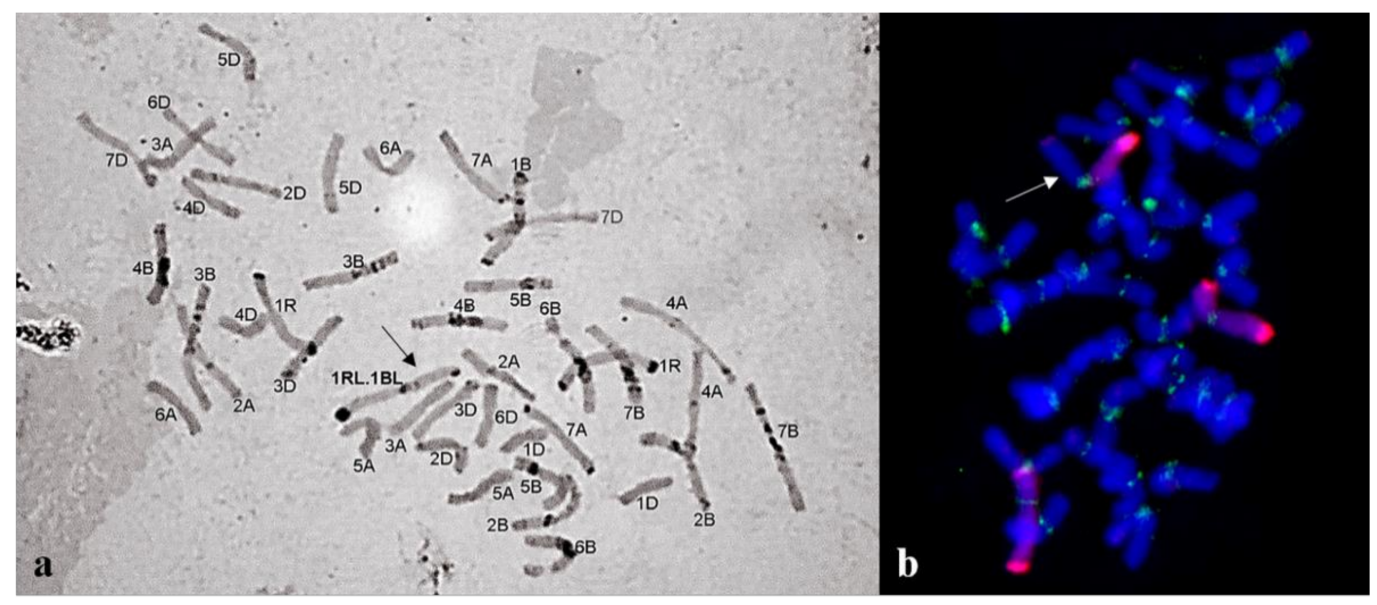

Figure 7. Chromosome sets of the same plant progeny of subgroup $1 \mathrm{~b}$ with a 1BL.1RL translocation $(2 n=42)$ (shown with an arrow): (a) C-banding; (b) GISH; rye chromosomes are labeled red and centromeres with green.

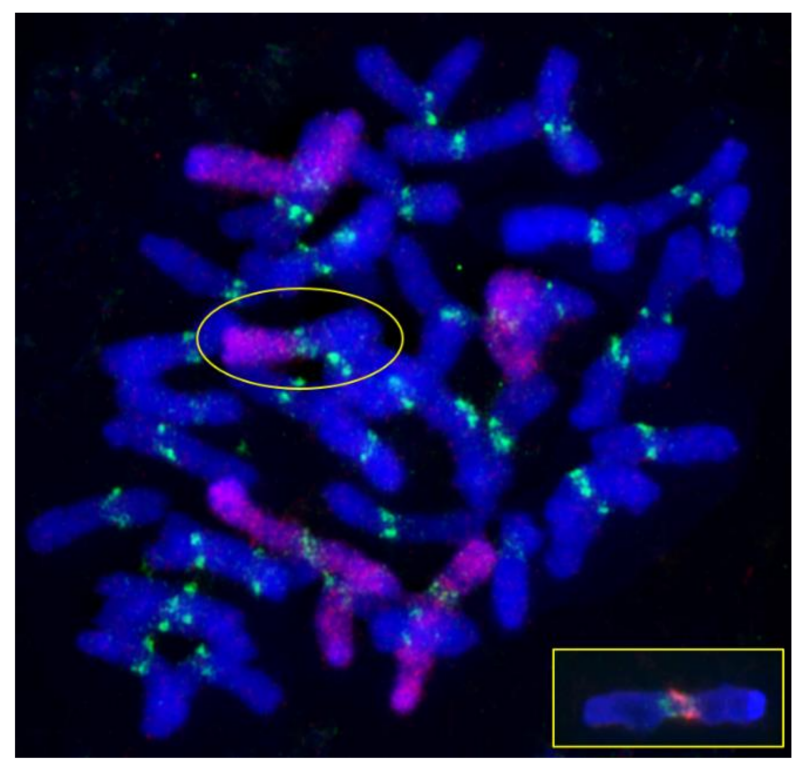

Figure 8. A chromosome set with a wheat-rye Robertsonian translocation (in circle). GISH, rye chromosomes are labeled red and pAet6-09, green. The inset shows the chromosome centromere with two non-overlapping probes pAet6-09 (green) and pAWRc (red).

\subsubsection{Group 2}

The chromosome sets of the $\mathrm{F}_{5}$ plants in Group 2 were relatively uniform. As shown by $\mathrm{C}$-banding, only two rye chromosomes were present in the disomic state: $1 \mathrm{R} 1 \mathrm{R}$ and 4R4R (Figures 9 and 10). 


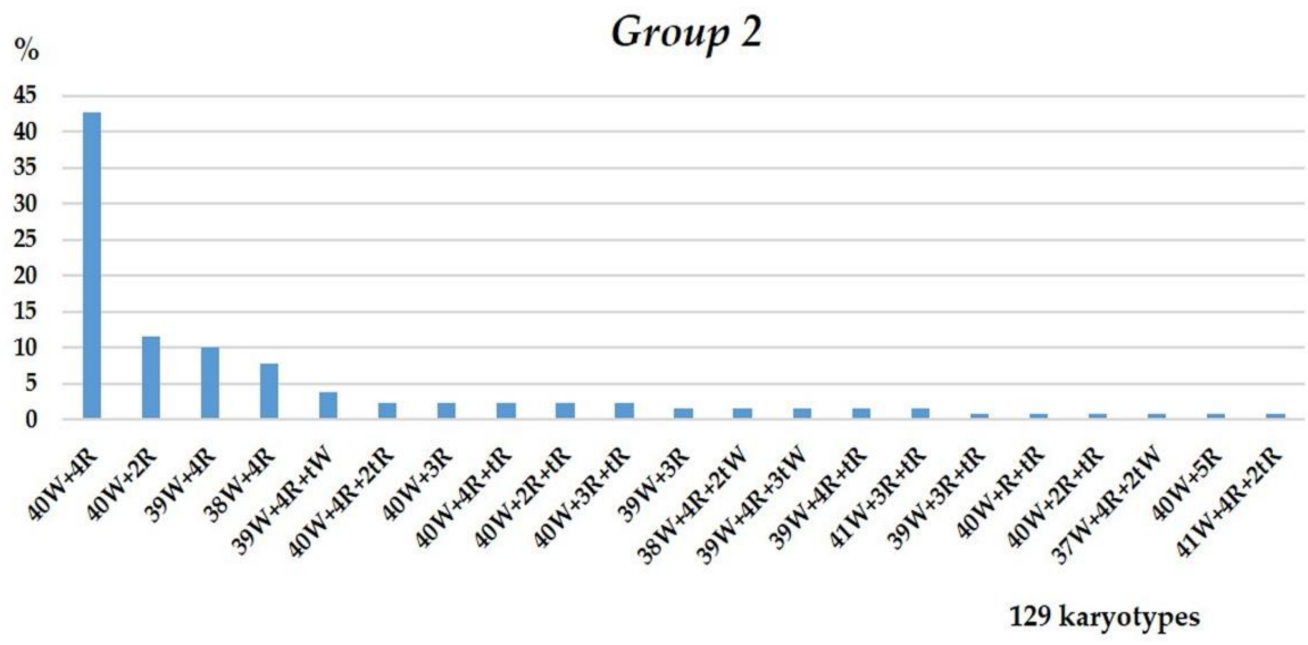

Figure 9. Frequencies of different chromosome sets in plant karyotypes of Group 2. Designations follow Figure 4.

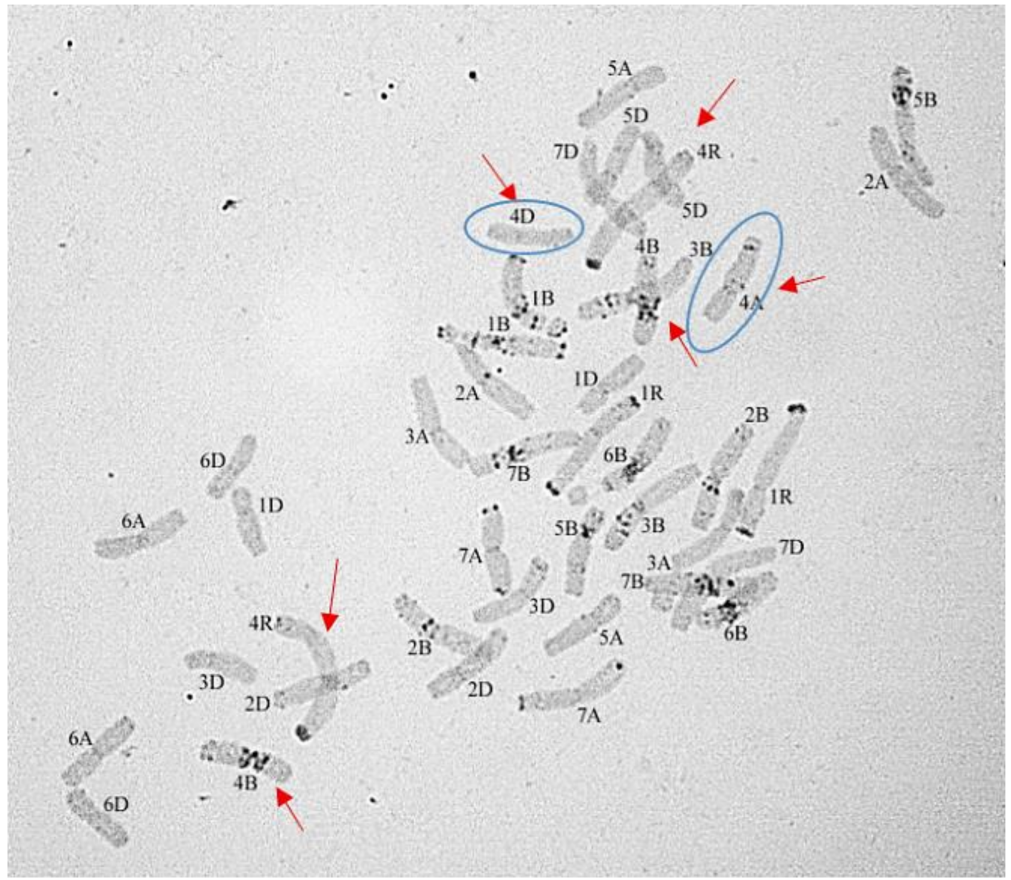

Figure 10. Karyotype with disomic substitution $1 \mathrm{R}(1 \mathrm{~A})$ and monosomic substitutions $4 \mathrm{R}(4 \mathrm{~A})$ and $4 \mathrm{R}(4 \mathrm{D}) 2 n=42$. C-banding.

The intergenomic substitution $1 \mathrm{R}(1 \mathrm{~A})$ was preserved in the first homeologous group in all sets. A $4 \mathrm{R} 4 \mathrm{R}$ pair was added to the whole set of common wheat chromosomes in $58.59 \%$ of sets. Alternatively, it replaced one of three wheat chromosomes of the fourth homeologous group in $13.15 \%$ of sets. Monosomic was observed in 11 chromosome sets (Figure 10), and disomic substitution in 6: in 1 plant with $4 \mathrm{R}(4 \mathrm{~A})$ substitution and in 5 with 4R(4B) (Table 3). Chromosome 4B was the most commonly eliminated or rearranged (19 plants, Table 3). Aneuploidy for chromosomes 6A, 5B, and 7D was detected in 11 plants-7, 1 , and 3 , respectively. 
Table 3. Combinations of rye and wheat chromosomes of the 4th homeologous group.

\begin{tabular}{|c|c|}
\hline Homeologous Group 4 & Plants/\% \\
\hline AABBDDRR & $76 / 58.9 \%$ \\
\hline A-BBDDRR & $1 / 0.77 \%$ \\
\hline AA-BDDRR & $4 / 3.1 \%$ \\
\hline AABB-DRR & $3 / 2.32 \%$ \\
\hline -BBDDRR & $1 / 0.77 \%$ \\
\hline AA-DDRR & $5 / 3.87 \%$ \\
\hline A-B-DDRR & $1 / 0.77 \%$ \\
\hline A-BB-DRR & $2 / 1.55 \%$ \\
\hline AABBDD-R & $3 / 2.32 \%$ \\
\hline AA-BDDR- & $1 / 0.77 \%$ \\
\hline AABBDD-RL & $2 / 1.55 \%$ \\
\hline AABBD-RRL & $1 / 0.77 \%$ \\
\hline AABBLDDRR & $1 / 0.77 \%$ \\
\hline AABLBLDDRR & $7 / 5.43 \%$ \\
\hline AABBDDRS- & $1 / 0.77 \%$ \\
\hline AABBDDRRR & $1 / 0.77 \%$ \\
\hline AABBDD- & $19 / 14.73 \%$ \\
\hline Total & $129 / 100 \%$ \\
\hline
\end{tabular}

\subsubsection{Group 3}

The chromosome numbers in Group 3 plants were nearly octoploid, varying from 52 to 56 . Plants with $2 n=56$ constituted $36.84 \% ; 52,14.03 \% ; 53,8.77 \% ; 54,26.3 \%$, and 55 , $14.03 \%$ (Figure 11 ).

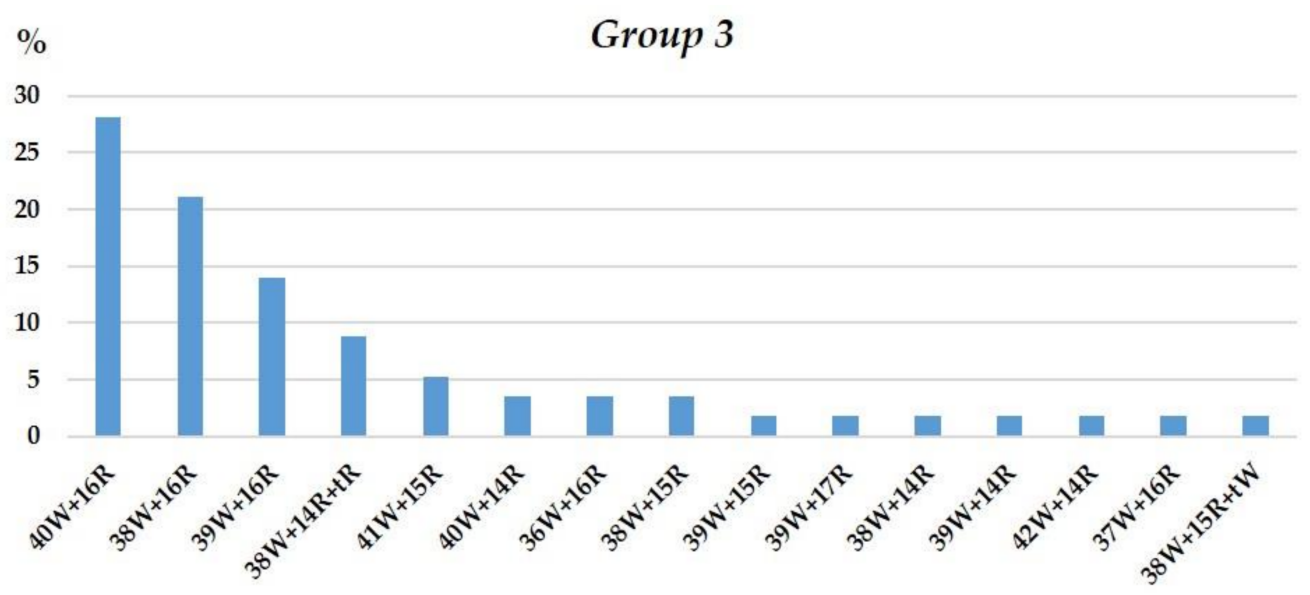

Figure 11. Frequencies of different chromosome sets in plant karyotypes of Group 3. Designations follow Figure 4.

The presence of 16 rye chromosomes owing to chromosome $1 \mathrm{R}$ tetrasomy ( $68.4 \%$ of plants) was a specific feature of the chromosome sets (Figure 11). The $40 \mathrm{~W}+16 \mathrm{R}$ chromosome combination was found in $28.07 \%$ of the sets. Four sets lacked one pair of $1 \mathrm{R}$ chromosomes, and one set lacked one $6 \mathrm{R}$ chromosome. Intergenomic substitution $1 \mathrm{R}(1 \mathrm{~A})$ was preserved in homeologous group 1 . It was found in all chromosome sets but four. Disomic and monosomic intergenomic substitutions of wheat chromosomes $3 \mathrm{R}(3 \mathrm{~A}), 6 \mathrm{R}(6 \mathrm{~A})$, 
$2 R(2 B), 3 R(3 D)$, and $4 R(4 D)$ were detected in nine plants, of which six showed substitutions of the chromosomes of homeologous group 3 (Figure 12). Chromosomes with altered structures were identified by GISH in only six plants-five with a rye telocentric and one with a wheat telocentric.

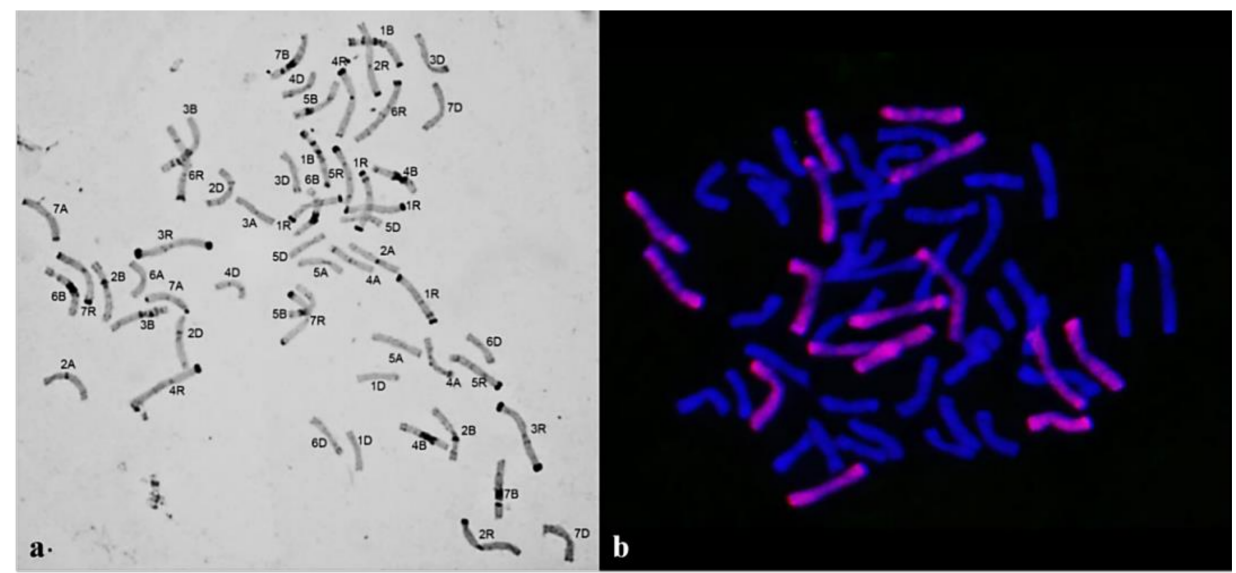

Figure 12. Chromosome sets of plants of Group 3: (a) Chromosome number $2 n=53,1 \mathrm{R}(1 \mathrm{~A})$ substitution, and monosomic substitutions 3R(3A) and 6R(6A), C-banding; (b) $2 n=56,40 \mathrm{~W}+16 \mathrm{R}$; GISH. Rye chromosomes are labeled red.

\subsection{Chromosome Behavior in Meiosis}

Chromosome behavior was studied in plants from Groups 1 and 3. The predominant meiotic aberrations in Group 1 were (i) the formation of univalents and their improper disjunction, leading to the formation of micronuclei, and (ii) cell cycle asynchronization (Figure 13).

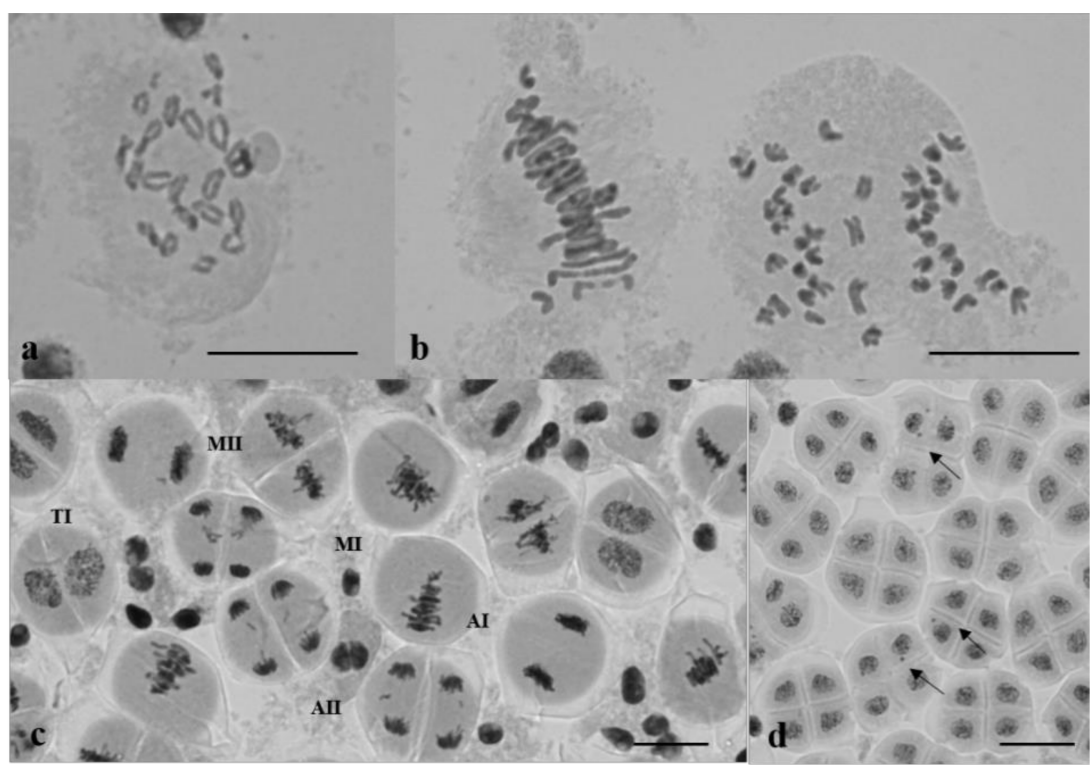

Figure 13. The behavior of chromosomes undergoing meiosis in plants of Group 1: (a) Diakinesischromosomes form bivalents; (b) metaphase I and anaphase I. Two univalents in a meiocyte at metaphase I; univalents arrested on the metaphase plate at anaphase I; (c) cell cycle asynchronization in meiocytes in one anther; meiocytes at MI-AII; (d) meiocytes at TII; micronuclei are shown with arrows. Staining acetocarmine. Scale bar $10 \mu \mathrm{m}$.

Meiocytes with univalents constituted $68.3 \pm 2.64 \%$ to $100 \%$ of subgroup $1 \mathrm{a}$ and $60 \pm 3.05$ to $92 \pm 2.16 \%$ of subgroup $1 b$ (progeny of plant $23-10$ ), and made up $32.4 \pm 1.05 \%$ 
of the progeny of plant 23-8. Univalents were lagged on the metaphase plate at anaphases I and II. The arrest of chromosomes on the metaphase plate at AII caused the formation of micronuclei at the tetrad stage. The counting of micronuclei in tetrads revealed differences within Group 1 and within each of its subgroups. In subgroup 1a, meiocytes with micronuclei constituted $47 \pm 3.75$ to $70.26 \pm 6.2 \%$ (Table 4 ).

Table 4. Micronucleus formation at telophase II and seed sets in $\mathrm{F}_{5}$ plants of Group 1.

\begin{tabular}{|c|c|c|c|c|c|}
\hline \multirow{2}{*}{ Hybrid $F_{1}$} & \multirow{2}{*}{ Hybrid $F_{2}$} & \multirow{2}{*}{ Hybrid $F_{3}$} & \multirow{2}{*}{ Hybrid $F_{4}$} & \multicolumn{2}{|l|}{ Hybrids $F_{5}$} \\
\hline & & & & Meiocytes with Micronuclei, \% & Seed Set \\
\hline \multirow{8}{*}{$4-7$} & \multirow{4}{*}{ 6-1 (subgroup 1a) } & \multirow{4}{*}{$22-4$} & $72-3$ & $47 \pm 3.75$ & $67 \pm 6.2$ \\
\hline & & & $72-4$ & $56.35 \pm 8.3$ & $61.83 \pm 9.2$ \\
\hline & & & $72-11$ & $70.26 \pm 6.2$ & $81.88 \pm 9.4$ \\
\hline & & & $72-12$ & $60.37 \pm 6.0$ & $102.47 \pm 9.3$ \\
\hline & \multirow{4}{*}{ 6-2 (subgroup 1b) } & $23-8$ & $76-1$ & $13.93 \pm 1.89$ & $55.93 \pm 6.7$ \\
\hline & & \multirow{3}{*}{$23-10$} & $77-1$ & $65.21 \pm 9.4$ & $37.19 \pm 8.5$ \\
\hline & & & $77-4$ & $46.5 \pm 2.45$ & $40.92 \pm 7.9$ \\
\hline & & & $77-8$ & $46.95 \pm 7.95$ & $40 \pm 6.2$ \\
\hline
\end{tabular}

The asynchronous cell cycle manifested itself as the presence of meiocytes from metaphase I to telophase II inside the same anther (Figure 13). Such anthers were noted in all plants, but their frequencies varied broadly, from 13.2 to $64 \%$. The frequency of anthers with asynchronous meiocyte division did not correlate with poor seed sets $(r=0.19)$.

In subgroup $1 \mathrm{~b}$, the lowest number of meiocytes with micronuclei was found in the progeny of plant $23-8: 13.93 \pm 1.89 \%$. In the progeny of 23-10, the percentage of meiocytes with micronuclei varied from $46.5 \pm 2.45$ to $65.21 \pm 9.4 \%$. Seed sets varied among plants within subgroups, and showed negligible correlations with micronucleus numbers, according to the Chaddock scale (Table 1, Figure 14).
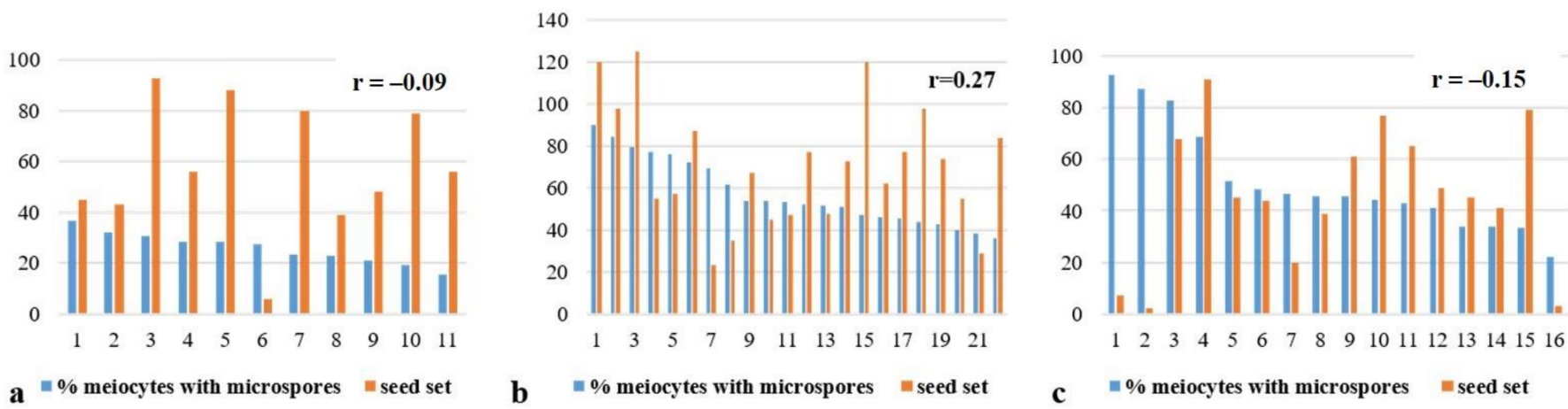

Figure 14. Absence of correlation between the frequency of micronuclei in meiosis and the seed set: (a) Subgroup 1a, 22-4 plant progeny; (b) subgroup 1b, 23-8 plant progeny; (c) subgroup 1b, 23-10 plant progeny. r-correlation coefficient.

The rye chromosomes $1 \mathrm{R} 1 \mathrm{R}$ and $4 \mathrm{R} 4 \mathrm{R}$ were identified in the chromosome sets of subgroup 1a. To understand the cause of the preservation of chromosomes $4 \mathrm{R} 4 \mathrm{R}$ up to generation $\mathrm{F}_{5}$, we analyzed the behavior of rye chromosomes at metaphase I and found that chromosomes $1 \mathrm{R} 1 \mathrm{R}$ and $4 \mathrm{R} 4 \mathrm{R}$ together formed $1.82 \pm 0.05$ rod and ring bivalents per meiocyte (Figure 15). Univalent rye chromosomes were detected in $17.8 \%$ of cells. 


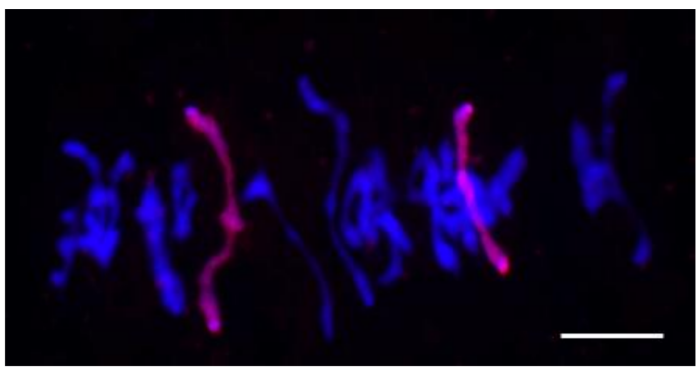

Figure 15. Rye chromosomes $1 \mathrm{R} 1 \mathrm{R}$ and $4 \mathrm{R} 4 \mathrm{R}$ form rod bivalents at metaphase $\mathrm{I}$. Scale bar $=40 \mu \mathrm{m}$.

Chromatin migration was also detected in meiosis. Cytomixis was identified in MI meiocytes and in pollen grains (Figure 16). Chromosome disjunction was not disturbed in donor cells (with fewer chromosomes). In contrast, the division machinery was inoperative in the recipient cells, and chromosomes occurred in indistinct clusters.

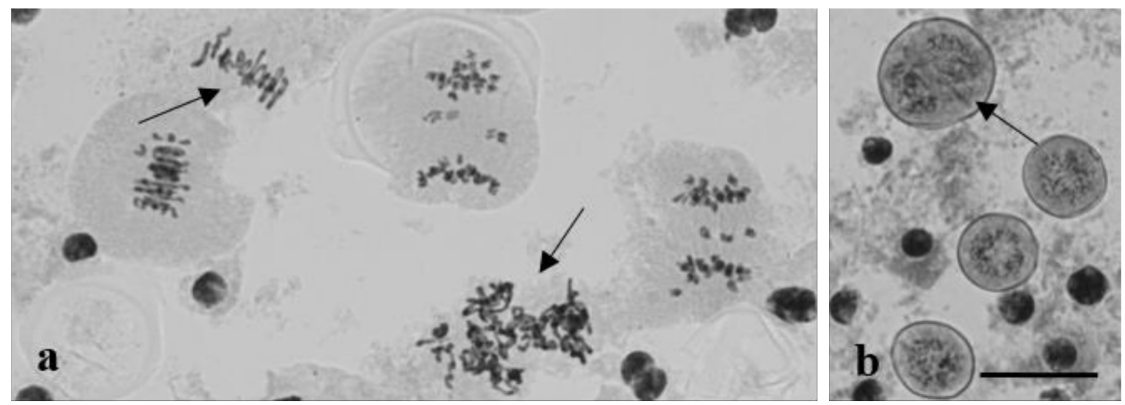

Figure 16. Cytomixis in meiosis in plants of Group 1: (a) Chromosomes in the donor cell behave normally, whereas abnormal chromosome behavior is observed in the recipient cell (shown with an arrow); (b) pollen grains of different sizes. Staining acetocarmine. Scale bar $=10 \mu \mathrm{m}$.

Univalents were found in $77.07 \pm 2.01 \%$ of the meiocytes in metaphase I in Group 3 plants. They were formed from both wheat and rye chromosomes (Figure 17a,b). Micronuclei were detected in $68.9 \pm 3.86 \%$ of the microsporocytes in telophase II (Figure 17d). Some meiocytes showed no chromosome pairing at all (Figure 17c).
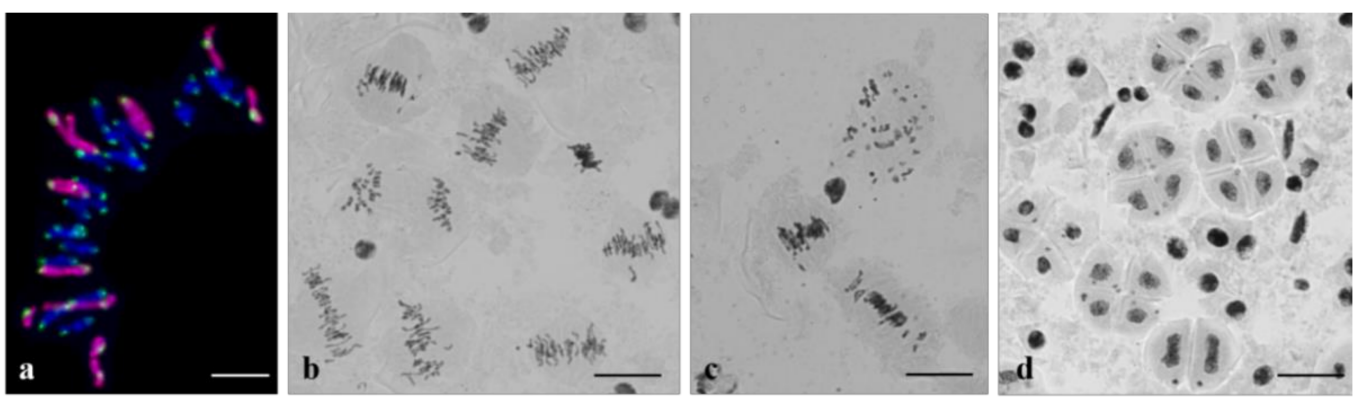

Figure 17. Typical chromosome behavior in meiosis in plants of Group 3: (a) Metaphase I; (b) metaphase I and anaphase I; (c) meiocyte without chromosome pairing; (d) tetrads with micronuclei and a dyad amid tetrads. (a) GISH; rye chromosomes are labeled red and pAet6-09, green; (b-d) acetocarmine. Scale bars $=40 \mu \mathrm{m}$ in $(\mathbf{a})$ and $10 \mu \mathrm{m}$ in $(\mathbf{b}-\mathbf{d})$.

Some cells displayed chromatin breakage and cytomixis (Figure 18). The migration of chromatin between a tapetum cell and a meiocyte was detected at prophase I, at which point its compaction changed. 


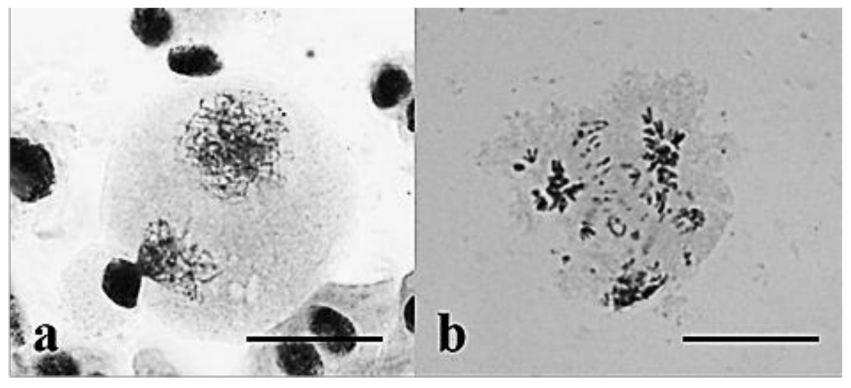

Figure 18. Meiotic aberrations in plants of Group 3. (a) Cytomixis; chromatin migrates between a tapetum cell and a meiocyte at prophase I. (b) Chromosome breaks at AI. Staining acetocarmine. Scale bar $=10 \mu \mathrm{m}$.

Asynchronous cell cycles were characteristic of meiosis in hybrids of this group. At the leptotene-zygotene stage, all anther meiocytes corresponded to this state (Figure 19a), whereas meiocytes corresponding to leptotene-zygotene was present in all subsequent meiotic phases, from pachytene to telophase II (Figure 19b-f).

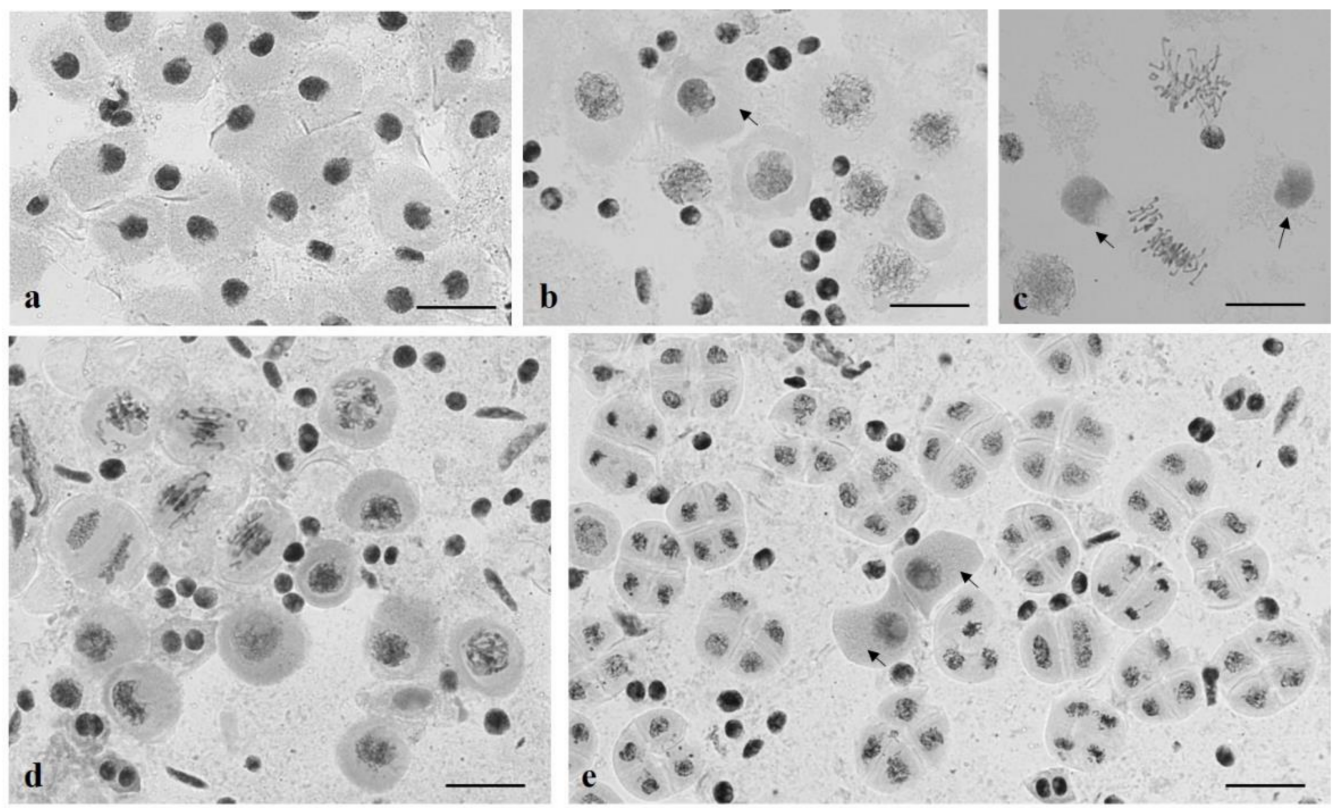

Figure 19. Meiocytes at early prophase stages retard in development in plants of Group 3. (a) The leptotene-zygotene stage; all meiocytes develop synchronously; (b) a meiocyte at the zygotene stage amid meiocytes at the pachytene stage; (c,d) meiocytes at prophase amid meiocytes at MI, TI; (e) a meiocyte at the zygotene stage amid meiocytes at the tetrad stage. Staining acetocarmine. Scale bar $=10 \mu \mathrm{m}$.

The omission of meiotic division II was observed in some plants, and dyads were identified among tetrads (Figure 20a). The percentage of dyads varied from 21.9 to 100 (Figure 20c). Significant aberrations in the mitotic division and chromatin structure were observed during pollen grain formation (Figure 20b). 


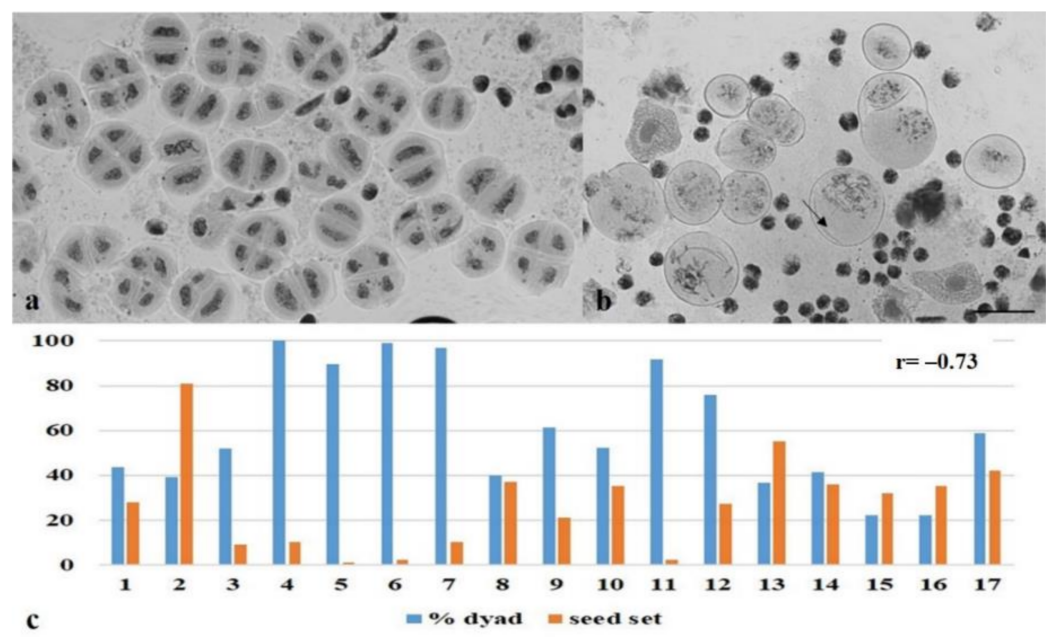

Figure 20. Dyad formation in plants of Group 3. (a) Dyads amid tetrads; (b) abnormal pollen grain development; meiocytes at the leptotene stage amid pollen grains (shown with an arrow); (c) The frequency of dyad formation inversely correlates $(r=-0.73)$ with seed set. $r$-correlation coefficient. Staining acetocarmine. Scale bar $=10 \mu \mathrm{m}$.

To summarize, the data on meiosis in particular plants and their fertility show that the high frequency of dyad formation is negatively correlated $(r=-0.73)$ with the seed set (Figure 20c). According to the Chaddock scale, a correlation coefficient $r=-0.73$ indicates high correlations with marked associations. Dyad formation and seed set were significantly associated (Student's $t$-test, $p \leq 0.001, \mathrm{df}=15$ ).

\section{Discussion}

\subsection{Chromosome Instability in $F_{5} 1 R v(1 A) \times R$ Hybrids}

Meiotic restitution (spontaneous chromosome duplication in gametes, yielding $2 \mathrm{n}$ gametes) in $F_{1}$ of interspecies and intergeneric hybrids is the means by which new polyploids (allopolyploids) arise in angiosperms [78-80]. The earliest wheat-rye hybrids, octoploid triticales, were also obtained by means of spontaneous chromosome duplication, including anthers as well as ovules [47]. Although triticales have a complete chromosome set, almost all newly formed triticales produce some chromosomally variable progeny $[47,49,65,81,82]$. In this study, the $\mathrm{F}_{1}$ hybrids from which $\mathrm{F}_{5}$ were obtained via self-pollination were produced using unreduced gametes. The unreduction occurs as follows: univalents congregate on the metaphase plate and separate into sister chromatids at AI. Then, two daughter nuclei are formed, and meiosis ends after meiosis I [64]. It was expected that the fusion of $2 n$ gametes would give rise to octoploid triticales. However, the analysis of the chromosome sets of the three groups studied revealed their different means of reorganization. A common feature of the chromosome sets of the three groups was the predominant transmission of chromosome $1 \mathrm{R}$, which replaces wheat chromosome $1 \mathrm{~A}$. This was predictable, as line $1 \operatorname{Rv}(1 \mathrm{~A})$ was used for hybridization to rye. One-third of Group 3 plants were octoploids $(2 n=56)$ bearing the tetrasome rye chromosome $1 \mathrm{R}$. Other chromosome sets showed aneuploidy for two rye chromosomes and five intergenomic substitutions for wheat chromosomes. In contrast, the chromosome sets in Groups 1 and 2 reverted to the ancestral substitution line $1 \operatorname{Rv}(1 \mathrm{~A})$. They retained 37 to 40 wheat chromosomes and eliminated four to five rye chromosome pairs. The $\mathrm{F}_{2}$ hybrid $7-4$, the ancestor of the $\mathrm{F}_{5}$ of Group 2, comprised a set of 46 chromosomes, with 40 wheat and 6 rye chromosomes (1R1R4R4R2RL2RL), as shown by C-banding [69]. The long arms 2RL2RL were preserved in the $F_{3}$ generation [69] and were eliminated by $F_{5}$. One reason for the absence of rye chromosomes from $\mathrm{F}_{2}$ might be their elimination in hybrid embryogenesis [69]. Alien chromosome elimination has been reported in crosses of wheat with Secale cereale, species of genus Hordeum, and species more distantly related to wheat, such as maize (Zea mays), 
pearl millet (Pennisetum glaucum), sorghum (Sorghum bicolor), and Imperata cylindrica [83-97]. The preferred elimination of wheat D-genome chromosomes in the first generations after synthetic wheat $(B B A A D D) \times$ rye $(R R)$ hybridization was also observed, and an $F_{2}$ seedling carrying 48 chromosomes was observed [56]. Hexaploid triticales with 28 intact $\mathrm{A} / \mathrm{B}$ and 14 intact $\mathrm{R}$ chromosomes, and with other chromosome constitutions, including monosomic, substitution, and translocation lines, were found in $\mathrm{F}_{5}$ of these hybrids $[54,56]$. Another reason for the absence of rye chromosomes from $\mathrm{F}_{2}$ may be meiotic irregularities in $F_{1}$, which produce laggard chromosomes and aneuploid gametes [98]. Alterations in chromosome disjunction in wheat-rye hybrids may produce gametes with chromosome numbers other than 21 or $28[65,81]$. The analysis of $\mathrm{F}_{2}$ T. aestivum $\mathrm{L} . \times$ S. cereale $\mathrm{L}$. indicated chromosome number variability. Plants in one group had the euploid chromosome number $2 n=56$, and others had aneuploid numbers 49 to 54 [81]. The same study showed that most of megaspores in $\mathrm{F}_{1}$ hybrids were aneuploid for one to four chromosomes, wheat or rye. Aneuploid plants were detected among hybrids T. turgidum L. $\times$ S. cereale L. using the meiotic restitution pathway: one was monosomic (41 chromosomes) for rye chromosome $3 \mathrm{R}$, two had 42 chromosomes each, one was a nullisomic-1R-tetrasomic-1B heterozygous for deficiency in approximately half of the long arm of chromosome $2 \mathrm{~B}$, and one was nullisomic-1R-trisomic-2A-trisomic-1B [65].

In this study, univalents and micronuclei were also formed in the meiosis of $\mathrm{F}_{5}$ hybrids, regardless of chromosome number and set completeness. Thus, genome reorganization was not completed in any of the three groups of wheat-rye $\mathrm{F}_{5}$ generation. Little is known about how long an allopolyploid chromosome set can remain unstable for, and how it can affect the allopolyploid evolution. Artificially resynthesized allopolyploids obtained by meiotic restitution mimic the allopolyploidization process. Studies in this field show different advances in the increase in stable allopolyploids in different taxa. An attempt to resynthesize the ancient polyploid Arabidopsis suecica by crossing A. thaliana and A. arenosa produced a viable hybrid, which showed homologous pairing and no important structural reorganization of the homeologous genomes in $\mathrm{F}_{5}$ [99]. In contrast, chromosomal variation is ubiquitous in newly developed synthetic hexaploid wheat (SHW) created by crossing T. turgidum with A. tauschii [100-102]. The common occurrence of univalency during meiotic metaphase I was associated with chromosome instability [102]. Young allopolyploids, termed neopolyploids, are appropriate evolutionary model systems for understanding early allopolyploid formation. Chromosome set instability is exemplified by the natural neoallotetraploids Tragopogon mirus and T. miscellus (about 40 generations). Aneuploids constitute 38 and $69 \%$ of these plants, respectively [103].

Cytological instability and aneuploidy in wheat-rye octoploid and hexaploid allopolyploids have presented problems since their creation $[47,49,104-106]$. The cytological study of triticale demonstrates that the interaction of wheat and rye genomes in the cells of one plant leads to profound derangements in cell physiology, which are maintained for decades at least. Thus, the same irregularities in meiosis and mitosis are noted in the triticale produced by Rimpau in 1889 as are found in triticale derived in later studies, including this one. In spite of the complete chromosome set, univalents are abundant in the meiosis of triticales of different ploidies [47,65,104-106]. In a comprehensive study of this phenomenon, only bivalents were found at diakinesis, but at MI, a pattern was established that can be interpreted as either chromosome lagging or the presence of a univalent. Aneuploid cells may arise in triticale as a result of the asynchronized functioning of rye and wheat chromosomes, and from chromosome lagging at the anaphase and telophase [105]. Chromosome disjunction depends on the proper functioning of the kinetochore [107]. As such, in stable hybrids, the CENH3 produced by one parent must be able to support the functionality of the other parent's centromeres, despite differences in each parent's centromere sequences [83]. Thus, the conservation of chromosome sets of the parental subgenomes in octoploid triticale over generations may be associated with the increased expression of rye centromeric histone CENH3 variants in the new genomic environment [108]. 


\subsection{Rye Chromosome $4 R$ Is Preserved until $F_{5}$ in $1 R v(1 A) \times R$ Hybrids}

Unexpectedly, we detected the preservation of rye $4 \mathrm{R}$ chromosomes in a monosomic or disomic state up until generation $\mathrm{F}_{5}$. While in $\mathrm{F}_{2}$, the chromosome pair $4 \mathrm{R} 4 \mathrm{R}$ only supplemented the wheat chromosome set [69], in $\mathrm{F}_{5}$, 4R4R was added to wheat chromosomes in $58.59 \%$ of plants and replaced chromosomes of the fourth homeologous group in $13.15 \%$ of plants, which implies its compensational and competitive activity in a new genomic environment. The short arm of chromosome $4 \mathrm{R}$ is known to be homeologous to wheat chromosome arms 4BS and 4DS, and partially homeologous to chromosome arm 4AL [109], which is itself involved in evolutionary translocations between chromosome arms $4 \mathrm{AL}$, $5 \mathrm{AL}$, and 7BS [37,39]. On the other hand, it has been shown that rye chromosomes are incorporated into the wheat genome at different frequencies depending on cross direction and genotype $[110,111]$. This is true for chromosome $4 R$ as well, which can be eliminated at high frequencies from triticale [111,112] or from disomic addition lines [113], but at the same time it can be successfully transmitted in crosses of wheat and octoploid triticale, which results in the $4 \mathrm{R}$ addition line [114] and in offspring from the substitution line [115]. The transmission rate of the $4 \mathrm{R}$ chromosome pair was consistent at $98 \%$ in subsequent generations [114]. In a study summarizing the genetic stability of several wheat-rye disomic addition lines, the frequency of progeny plants being disomic for $4 \mathrm{R}$ ranged from $74 \%$ to $93 \%$ [116]. In our study, the preservation of the $4 R$ chromosome copy in $F_{5} 1 R v(1 \mathrm{~A}) \times R$ likely results from the great similarity to corresponding homeologs in the genomes of wheat, similarly to the preservation of rye genes in allohexaploid triticale with a high similarity to their homeologs in Triticum genomes [117].

\subsection{Alterations of Centromeric Regions}

Deletions and translocations of individual chromosomal regions and chromosome arms are also among the most common chromosomal alterations $[57,106]$. The chromosome sets of our $\mathrm{F}_{5}$ hybrids contain rye and wheat telocentrics and Robertsonian translocations. The formation of inter- and intrachromosomal translocations in wheat-rye hybrids cause reductions, eliminations, or expansions in the centromeric retrotransposon sequences, and the formation of multiple centromeres [53,59]. In our experiments, a centromere carrying two nonoverlapping loci, rye-specific pAWRc and pAet06, was identified in a 1RL.1BL Robertsonian translocation. Multicentric chromosomes are frequently formed in hybrids of wheat and related species, such as Th. elongatum, Th. poticum, Th. intermedium, Agropyron cristatum, Hordeum vulgare, and S. cereale [59]. Wheat and Th. elongatum chromosomes with two regions containing centromeric sequences were observed in the $\mathrm{F}_{1}$ hybrids of null-tetra lines N3AT3B, N5BT5A, N5DT5B, and N6AT6B, and in the hexaploid amphiploid 8802 (AABBEE), which originated from hybrids between T. durum and Th. elongatum [59].

\subsection{Meiotic Restitution Does Not Increase Ploidy in Progenitors of Octoploid Triticale}

The heritability of meiotic restitution has been described in wheat hybrids $[54,67,101]$. The genes for meiotic restitution in those studies originated from various accessions of durum wheat T. turgidum [65-68]. Lines of synthetic hexaploid wheat (SHW) were produced by spontaneous chromosome doubling via unreduced gametes resulting from meiotic restitution in T. turgidum $\times$ A. tauschii hybrids [66]. These hexaploids also inherited the gene(s) for meiotic restitution, because meiotic restitution also occurs in SHW-rye $F_{1}$ hybrids and gives rise to amphiploids or partial amphiploids [66]. Another example is line Do1, which was selected for its capacity to produce self-fertile $F_{1}$ hybrids with rye $[65,67]$. Spontaneous chromosome duplication in androgenic haploids was observed when crossing the $\mathrm{F}_{1}$ hybrid to hexaploid triticale [67].

Three groups of $\mathrm{F}_{5} 1 \mathrm{Rv}(1 \mathrm{~A}) \times \mathrm{R}$ hybrids were obtained via meiotic restitution, whereby chromosome pairing occurs sporadically if at all, univalents segregate into sister chromatids in meiosis I, and the second division is absent $[64,118]$. We found that the meiosis in some $\mathrm{F}_{5}$ plants of Group 3 also ended after the first division; therefore, dyads formed after division completion instead of tetrads. Another feature of chromosome behavior was the 
asynchronization of the meiotic cycle within an anther. Asynchronous cell division was also noted in $\mathrm{F}_{5}$ plants of Groups 1 and 2, but the second division did occur there. An Arabidopsis thaliana mutant named tardy asynchronous meiosis (tam), with a phenotype of delayed and asynchronous cell divisions during male meiosis, has been described [119]. The genes TAM (also known as CYCA1;2) and OSD1 (omission of second division) are essential for the meiosis I/meiosis II transition. A mutation in CYCA1;2/TAM or OSD1 leads to the premature ending of meiosis after meiosis $\mathrm{I}$, and, as a consequence, to the production of diploid spores and gametes $[120,121]$. Hence, mutations in such genes as OSD1 and TAM may favor polyploidization, as demonstrated in common wheat. A QTL responsible for the unreduction in T. turgidum $\times$ Ae. tauschii hybrids, named QTug.sau-3B, was identified on wheat chromosome 3B [122]. Comparative genomic analysis indicates that QTug.sau-3B is a collinear homolog of cyca1;2/tam, which is known to be responsible for unreduced gamete formation in Arabidopsis thaliana [121].

Whilst dyads in $\mathrm{F}_{1}$ hybrids $1 \operatorname{Rv}(1 \mathrm{~A}) \times \mathrm{R}$ passed through mitotic divisions and formed functional pollen grains after meiosis, the mitotic division in octoploid $F_{5}$ hybrids was greatly disturbed. The disturbances affected chromatin's structure significantly. As a result, functional pollen grains were not formed, and plants either offered few seeds or were totally sterile. Arabidopsis thaliana osd1 mutants showed no somatic developmental defects, male or female gametophyte lethality, or reduced fertility. Only tetraploids and triploids were found in selfed progeny [123]. In plants homozygous for null alleles of CYCA1;2/TAM, the unreduced gametes were functional, giving rise to polyploid progeny $[121,124]$. The chromosome number in each generation of MiMe plants' selfing (mitosis instead of meiosis, triple osd1/Atrec8/Atspo11-1 mutants) doubled; as such, tetraploids (4n, 20 chromosomes) and octoploids ( $8 n, 40$ chromosomes) were obtained [123]. However, the increase in ploidy was accompanied by a seed set decrease. Fertility dropped from $25 \pm 6$ seeds/fruit in $2 n$ plants and $19 \pm 4$ in $4 \mathrm{n}$ plants to $<0.1$ in $8 n$ plants. The causes of this phenomenon remain obscure. In the case of octoploid plants $1 \operatorname{Rv}(1 \mathrm{~A}) \times \mathrm{R}$, the formation of microspores with 56 chromosomes may induce stress, entailing a collapse in cell cycle regulation and, as a consequence, apoptosis [125]. The Poaceae family includes perennial plants with over 100 chromosomes [126]. They are characterized by low fertility and sterility, probably associated with meiotic anomalies induced by polyploidy. Studies of the genus Arundo L. (Poaceae) have demonstrated that the sterility of A. micrantha $(2 n=12 x)$ and A. donax $(2 n=18 \mathrm{x})$ is due to the early failure of gametogenesis [127]. In theory, unreduced gametes form during meiosis in these species; however, these gametes have not been proven to cause sterility.

Is there a limit to ploidy in flowering plants? Although the haploid chromosome numbers in 66120 angiosperm species with known chromosome sets vary from $n=2$ to $n=320$ [126], the chromosome numbers of $80 \%$ of angiosperms range from $n=5$ to 20 , and in $95 \%$ the haploid chromosome numbers are less than $n=34$. A similar distribution in chromosome numbers is seen in the tribe Triticeae. All the species of this tribe have the basic haploid chromosome number $x=7$. About $31 \%$ of the species are diploids (or rather paleopolyploids); $1 \%$ are triploids; $45 \%$, tetraploids; $17 \%$, hexaploids; $5 \%$, octoploids; $0.2 \%$, decaploids; and $0.2 \%$, dodecaploids. Elymus displays the larger series and highest level of polyploidy, from $2 x$ to $12 x$ [20]. Owing to the cyclic mode of polyploidy, most angiosperm species have less than 14 chromosome pairs, which show no signs of exponential growth [128]. Genome synteny comparisons show that many ancient polyploidization events were followed by striking reductions in chromosome number [16], which in some cases are estimated to have occurred relatively soon after polyploidization [129]. For instance, an $n=7$ monocot ancestor underwent four tetraploidy events in the lineage leading to Zea mays; had not it been for fusions, maize would have $n=112$, but today it has $n=10$ [130]. On the other hand, chromosome sizes cannot rise infinitely after fusion. Chromosome lengths are limited by the sizes of the dividing cells; chromosome arms longer than half the cell length are truncated by the new cell wall, causing damage and gene loss at the ends [131], as proven experimentally with artificial chromosomes in barley [132]. Ploidy 
increase may also be limited by other factors as well [133]. These include biochemical and energetical expenses, cell size limits, time limitations caused by longer mitosis and meiosis with larger genomes, and difficulties in support of gene expression diversity in giant genomes in response to environmental changes.

\section{Conclusions}

In this work, we studied the karyotypes and meiotic behavior of chromosomes in three groups of fifth-generation hybrids $(1 \mathrm{Rv}(1 \mathrm{~A}) \times \mathrm{R})$ obtained via meiotic restitution. Our observations suggest that genome reorganization is not finished in any of the groups of $\mathrm{F}_{5}$ hybrids. It was found that in two groups of karyotypes, one to three rye chromosomes were preserved in a disomic or monosomic state. The chromosome $4 \mathrm{R}$ in $13.15 \%$ of plants substituted the chromosomes of the fourth group of wheat genomes, ABD. The karyotypes of the plants of these groups were also characterized by the presence of Robertsonian translocations. The chromosome sets of Group 3 were near octoploid, varying from 52 to 56 . The presence of 16 rye chromosomes owing to chromosome $1 \mathrm{R}$ tetrasomy $(68.4 \%$ of plants) was a distinctive feature.

Meiosis in the hybrids was unstable. Univalents in the first division were found, characterized by a violation of segregation, which led to the formation of micronuclei in microspores. However, according to the correlation analysis, no connection was found between the presence of micronuclei and seed sets. The analysis of meiosis in Group 3 revealed asynchronous cell division and omission of the second division. Diploid gametes did not form because of significant disturbances during mitosis in gametogenesis. As a result, the frequency of the formed dyads was negatively correlated $(r=-0.73)$ with the seed sets. Thus, the trait "meiotic restitution" is inherited in octoploid triticale; however, gametogenesis does not take place in dyads, and functional gametes are not formed.

Supplementary Materials: The following are available online at https:/ / www.mdpi.com/article/10 .3390 / plants10102052/s1, Table S1: Origin of $\mathrm{F}_{5}$ wheat-rye hybrids and number of karyotype studied.

Author Contributions: O.G.S. planned experiments and wrote the manuscript; Y.N.I. and D.B.L. performed FISH analyses; L.A.S. and N.I.D. performed C-banding; E.A.S. and O.G.S provided resources; N.I.D. and O.G.S. performed data curation; N.I.D. and O.G.S. reviewed and edited the manuscript. All authors have read and agreed to the published version of the manuscript.

Funding: The work was supported by state budgeted project 0259-2021-0012 for the Institute of Cytology and Genetics.

Institutional Review Board Statement: Not applicable.

Informed Consent Statement: Not applicable.

Data Availability Statement: Data are contained within the article or supplementary material.

Acknowledgments: We are grateful to the staff of the Shared Access Center for Microscopy Analysis of Biologic Objects, Siberian Branch of the RAS.

Conflicts of Interest: The authors declare no conflict of interest.

\section{References}

1. Soltis, P.S.; Marchant, D.B.; Van de Peer, Y.; Soltis, D.E. Polyploidy and genome evolution in plants. Curr. Opin. Genet. Dev. 2015, 35, 119-125. [CrossRef] [PubMed]

2. Wendel, J.F.; Jackson, S.A.; Meyers, B.C.; Wing, R.A. Evolution of plant genome architecture. Genome Biol. 2016, 17, 1-14. [CrossRef] [PubMed]

3. Soltis, P.S.; Soltis, D.E. The role of hybridization in plant speciation. Annu. Rev. Plant Biol. 2009, 60, 561-588. [CrossRef] [PubMed]

4. Ramsey, J.; Schemske, D.W. Pathways, mechanisms, and rates of polyploid formation in flowering plants. Annu. Rev. Ecol. Syst. 1998, 29, 467-501. [CrossRef]

5. Alix, K.; Gérard, P.R.; Schwarzacher, T.; Heslop-Harrison, J.S. Polyploidy and interspecific hybridisation: Partners for adaptation, speciation and evolution in plants. Ann. Bot. 2017, 120, 183-194. [CrossRef]

6. Jones, R.N.; Hegarty, M. Order out of chaos in the hybrid plant nucleus. Cytogenet. Genome Res. 2009, 126, 376-389. [CrossRef]

7. McClintock, B. The significance of responses of the genome to challenge. Science 1984, 226, 792-801. [CrossRef] 
8. Chen, Z.J. Genetic and epigenetic mechanisms for gene expression and phenotypic variation in plant polyploids. Annu. Rev. Plant Biol. 2007, 58, 377-406. [CrossRef] [PubMed]

9. Doyle, J.J.; Flagel, L.E.; Paterson, A.H.; Rapp, R.A.; Soltis, D.E.; Soltis, P.S.; Wendel, J.F. Evolutionary genetics of genome merger and doubling in plants. Annu. Rev. Genet. 2008, 42, 443-461. [CrossRef]

10. Jackson, S.; Chen, Z.J. Genomic and expression plasticity of polyploidy. Curr. Opin. Plant Biol. 2010, 13, 153-159. [CrossRef]

11. Grover, C.; Gallagher, J.; Szadkowski, E.; Yoo, M.; Flagel, L.; Wendel, J. Homoeolog expression bias and expression level dominance in allopolyploids. New Phytol. 2012, 196, 966-971. [CrossRef]

12. Hughes, T.E.; Langdale, J.A.; Kelly, S. The impact of widespread regulatory neofunctionalization on homeolog gene evolution following whole-genome duplication in maize. Genome Res. 2014, 24, 1348-1355. [CrossRef]

13. Renny-Byfield, S.; Wendel, J.F. Doubling down on genomes: Polyplidy and crop plants. Am. J. Bot. 2014, 101, 1711-1725. [CrossRef]

14. Panchy, N.; Lehti-Shiu, M.; Shiu, S.-H. Evolution of gene duplication in plants. Plant Physiol. 2016, 171, 2294-2316. [CrossRef]

15. Miryeganeh, M.; Saze, H. Epigenetic inheritance and plant evolution. Popul. Ecol. 2020, 62, 17-27. [CrossRef]

16. Wendel, J.F. The wondrous cycles of polyploidy in plants. Am. J. Bot. 2015, 102, 1753-1756. [CrossRef]

17. Leitch, A.; Leitch, I. Genomic plasticity and the diversity of polyploid plants. Science 2008, 320, 481-483. [CrossRef] [PubMed]

18. Heslop-Harrison, J.S.; Schwarzacher, T. Organization of the plant genome in chromosomes. Plant J. 2011, 66, 18-33. [CrossRef] [PubMed]

19. International Wheat Genome Sequencing Consortium. A chromosome-based draft sequence of the hexaploid bread wheat genome. Science 2014, 345, 1251788. [CrossRef] [PubMed]

20. Feldman, M.; Levy, A.A. Origin and evolution of wheat and related Triticeae species. In Alien Introgression in Wheat; Molnar-Lang, M., Ceoloni, C., Dolezel, J., Eds.; Springer International: Cham, Switzerland, 2015; pp. 21-76.

21. Pont, C.; Salse, J. Wheat paleohistory created asymmetrical genomic evolution. Curr. Opin. Plant Biol. 2017, 36, 29-37. [CrossRef]

22. Akhunov, E.D.; Akhunova, A.R.; Anderson, O.D.; Anderson, J.A.; Blake, N.; Clegg, M.T.; Coleman-Derr, D.; Conley, E.J.; Crossman, C.C.; Deal, K.R.; et al. Nucleotide diversity maps reveal variation in diversity among wheat genomes and chromosomes. BMC Genom. 2010, 11, 702. [CrossRef]

23. Pont, C.; Murat, F.; Confolent, C.; Balzergue, S.; Sals, J. RNA-seq in grain unveils fate of neo- and paleopolyploidization events in bread wheat (Triticum aestivum L.). Genome Biol. 2011, 12, R119. [CrossRef] [PubMed]

24. Feldman, M.; Levy, A.A. Genome evolution due to allopolyploidization in wheat. Genetics 2012, 192, 763-774. [CrossRef]

25. Pont, C.; Murat, F.; Guizard, S.; Flores, R.; Foucrier, S.; Bidet, Y.; Quraishi, U.M.; Alaux, M.; Doleel, J.; Fahima, T.; et al. Wheat syntenome unveils new evidences of contrasted evolutionary plasticity between paleo- and neoduplicated subgenomes. Plant. J. 2013, 76, 1030-1044. [CrossRef] [PubMed]

26. Pfeifer, M.; Kugler, K.G.; Sandve, S.R.; Zhan, B.; Rudi, H.; Hvidsten, T.R.; International Wheat Genome Sequencing Consortium; Mayer, K.F.; Olsen, O.A. Genome interplay in the grain transcriptome of hexaploid bread wheat. Science 2014, 345, 1250091. [CrossRef] [PubMed]

27. Liu, Z.; Xin, M.; Qin, J.; Peng, H.; Ni, Z.; Yao, Y.; Sun, Q. Temporal transcriptome profiling reveals expression partitioning of homeologous genes contributing to heat and drought acclimation in wheat (Triticum aestivum L.). BMC Plant Biol. 2015, 15, 152. [CrossRef] [PubMed]

28. Zhang, Z.; Gou, X.; Xun, H.; Bian, Y.; Ma, X.; Li, J.; Lia, N.; Gong, L.; Feldman, M.; Liu, B.; et al. Homoeologous exchanges occur through intragenic recombination generating novel transcripts and proteins in wheat and other polyploids. Proc. Natl. Acad. Sci. USA 2020, 117, 14561-14571. [CrossRef]

29. Murat, F.; Zhang, R.; Guizard, S.; Flores, R.; Armero, A.; Pont, C.; Steinbach, D.; Quesneville, H.; Cooke, R.; Salse, J. Shared subgenome dominance following polyploidization explains grass genome evolutionary plasticity from a seven protochromosome ancestor with 16K protogenes. Genome Biol. Evol. 2014, 6, 12-33. [CrossRef]

30. Naranjo, T.; Roca, A.; Goicoechea, P.G.; Giraldez, R. Arm homoeology of wheat and rye chromosomes. Genome 1987, $29,873-882$. [CrossRef]

31. Naranjo, T. Chromosome structure of durum wheat. Theor. Appl. Genet. 1990, 79, 397-400. [CrossRef]

32. Liu, C.J.; Atkinson, M.D.; Chinoy, C.N.; Devos, K.M.; Gale, M.D. Nonhomoeologous translocations between group 4,5 and 7 chromosomes within wheat and rye. Theor. Appl. Genet. 1992, 83, 305-312. [CrossRef]

33. Jiang, J.; Gill, B.S. Different species-specific chromosome translocations in Triticum timopheevii and T. turgidum support the diphyletic origin of polyploid wheats. Chromosome Res. 1994, 2, 59-64. [CrossRef]

34. Rodríguez, S.; Perera, E.; Maestra, B.; Díez, M.; Naranjo, T. Chromosome structure of Triticum timopheevii relative to T. turgidum. Genome 2000, 43, 923-930. [CrossRef]

35. Salina, E.A.; Leonova, I.N.; Efremova, T.T.; Roder, M.S. Wheat genome structure: Translocations during the course of polyploidization. Funct. Integr. Genom. 2006, 6, 71-80. [CrossRef]

36. Badaeva, E.D.; Dedkova, O.S.; Pukhalskyi, V.A.; Zelenin, A.V. Chromosomal changes over the course of polyploid wheat evolution and domestication. In Advances in Wheat Genetics: From Genome to Field; Ogihara, Y., Takumi, S., Handa, H., Eds.; Springer: Tokyo, Japan, 2015; pp. 83-89. 
37. Badaeva, E.D.; Chikida, N.N.; Fisenko, A.N.; Surzhikov, S.A.; Belousova, M.K.; Özkan, H.; Dragovich, A.Y.; Kochieva, E.Z. Chromosome and molecular analyses reveal significant karyotype diversity and provide new evidence on the origin of Aegilops columnaris. Plants 2021, 10, 956. [CrossRef]

38. Badaeva, E.D.; Chikida, N.N.; Belousova, M.K.; Ruban, A.S.; Surzhikov, S.A.; Zoshchuk, S.A. A new insight on the evolution of polyploid Aegilops species from the complex Crassa: Molecular-cytogenetic analysis. Plant Syst. Evol. 2021, 307, 3. [CrossRef]

39. Parisod, C.; Badaeva, E.D. Chromosome restructuring among hybridizing wild wheats. New Phytol. 2020, $226,1263-1273$. [CrossRef] [PubMed]

40. Sattler, M.C.; Carvalho, C.R.; Clarindo, W.R. The polyploidy and its key role in plant breeding. Planta 2016, 243, 281-296. [CrossRef] [PubMed]

41. Kocheshkova, A.A.; Kroupin, P.Y.; Bazhenov, M.S.; Karlov, G.I.; Pochtovyy, A.A.; Upelniek, V.P.; Belov, V.I.; Divashuk, M. GPre-harvest sprouting resistance and haplotype variation of ThVp-1 gene in the collection of wheat-wheatgrass hybrids. PLoS ONE 2017, 12, e0188049. [CrossRef] [PubMed]

42. Muntzing, A. Historical review of the development of triticale. In Triticale, Proceedings of an International Symposium, El Batan, Mexico; Development Research Centre: Ottawa, ON, Canada, 1974; pp. 13-30.

43. Meister, G.K. Natural hybridization of wheat and rye in Russia. J. Hered. 1921, 12, 467-470. [CrossRef]

44. Levitsky, G.A.; Benetzkaja, G.K. Cytological investigations of constant intermediate rye-wheat hybrids. In Proceedings of the Allunion Congress of Genetics Selek, Leningrad, Russia, 10-16 January 1929; pp. 345-352, (In Russian with English summary).

45. Ma, X.F.; Fang, P.; Gustafson, J.P. Polyploidization-induced genome variation in triticale. Genome 2004, 47, 839-848. [CrossRef]

46. Ma, X.F.; Gustafson, J.P. Timing and rate of genome variation in triticale following allopolyploidization. Genome 2006, 49, 950-958. [CrossRef]

47. Ma, X.F.; Gustafson, J.P. Allopolyploidization-accommodated genomic sequence changes in Triticale. Ann. Bot. 2008, 101, 825-832. [CrossRef]

48. Bento, M.; Pereira, H.S.; Rocheta, M.; Gustafson, P.; Viegas, W.; Silva, M. Polyploidization as a Retraction Force in Plant Genome Evolution: Sequence Rearrangements in Triticale. PLoS ONE 2008, 3, e1402. [CrossRef] [PubMed]

49. Tang, Z.X.; Fu, S.L.; Ren, Z.L.; Zhou, J.P.; Yan, B.J.; Zhang, H.Q. Variation of tandem repeat, regulatory element, and promoter regions revealed by wheat-rye amphiploids. Genome 2008, 51, 399-408. [CrossRef]

50. Martín, A.C.; Borrill, P.; Higgins, J.; Alabdullah, A.; Ramírez-González, R.H.; Swarbreck, D.; Uauy, C.; Shaw, P.; Moore, G. Genome-Wide Transcription During Early Wheat Meios Is Independent of Synapsis, Ploidy Level, and the Ph1 Locus. Front. Plant Sci. 2018, 9, 1791. [CrossRef] [PubMed]

51. Badaeva, E.D.; Badaev, N.S.; Bolsheva, N.L.; Zelenin, A.V. Chromosome alterations in the karyotype of triticale in comparison with the parental forms I. Heterochromatic regions of R genome chromosomes. Theor. Appl. Genet. 1986, 72, 518-523. [CrossRef] [PubMed]

52. Bolsheva, N.L.; Badaeva, E.D.; Badaev, N.S.; Zelenin, A.V. Chromosome alterations in the karyotype of triticale in comparison with the parental forms 2. Heterochromatin of the wheat chromosomes. Theor. Appl. Genet. 1986, 73, 66-71. [CrossRef] [PubMed]

53. Fu, S.; Lv, Z.; Guo, X.; Zhang, X.; Han, F. Alteration of Terminal Heterochromatin and Chromosome Rearrangements in Derivatives of Wheat-rye Hybrids. JGG 2013, 40, 413-420. [CrossRef]

54. Hao, M.; Luo, J.; Zhang, L.; Yuan, Z.; Yang, Y.; Wu, M.; Chen, W.; Zheng, Y.; Zhang, H.; Liu, D. Production of hexaploid triticale by a synthetic hexaploid wheat-rye hybrid method. Euphytica 2013, 193, 347-357. [CrossRef]

55. Tang, Z.; Li, M.; Chen, L.; Wang, Y.; Ren, Z.; Fu, S. New types of wheat chromosomal structural variations in derivatives of wheat-rye hybrids. PLoS ONE 2014, 9, e110282. [CrossRef]

56. Li, H.; Guo, X.; Wang, C.; Ji, W. Spontaneous and divergent hexaploid Triticales derived from common wheat $\times$ rye by complete elimination of D-genome chromosomes. PLoS ONE 2015, 10, e0120421. [CrossRef]

57. Lukaszewski, A.J. Introgressions between Wheat and Rye. In Alien Introgression in Wheat; Molnár-Láng, M., Ceoloni, C., Doležel, J., Eds.; Springer International Publishing: Cham, Switzerland, 2015; pp. 163-189.

58. Dubovets, N.I.; Sycheva, Y.A. Microevolutionary differentiation of cereal tetraploid species by formation of recombinant genomes Vavilovskii Zhurnal Genetiki i Selektsii Vavilov J. Genet. Breed. (In Russian with English summary). 2016, 20, 378-385. [CrossRef]

59. Guo, X.; Su, H.; Shi, Q.; Fu, S.; Wang, J.; Zhang, X.; Hu, Z.; Han, F. De Novo Centromere Formation and Centromeric Sequence Expansion in Wheat and its Wide Hybrids. PLoS Genet. 2016, 12, e1005997. [CrossRef]

60. Ramsey, J.; Schemske, D.W. Neopolyploidy in flowering plants. Annu. Rev. Ecol. Syst. 2002, 33, 589-639. [CrossRef]

61. Otto, S.P. The evolutionary consequences of polyploidy. Cell 2007, 131, 452-462. [CrossRef] [PubMed]

62. Kreiner, J.M.; Kron, P.; Husband, B.C. Frequency and maintenance of unreduced gametes in natural plant populations: Associations with reproductive mode, life history and genome size. New Phytol. 2017, 214, 879-889. [CrossRef]

63. Husband, B.C. The role of triploid hybrids in the evolutionary dynamics of mixed-ploidy populations. Biol. J. Linn. Soc. 2004, 82, 537-546. [CrossRef]

64. Silkova, O.G.; Loginova, D.B. Sister chromatid separation and monopolar spindle organization in the first meiosis as two mechanisms of unreduced gametes formation in wheat-rye hybrids. Plant Reprod. 2016, 29, 199-213. [CrossRef] [PubMed]

65. Olesczuk, S.; Lukaszewski, A.J. The origin of unusual chromosome constitutions among newly formed allopolyploids. Am. J. Bot. 2014, 101, 318-326. [CrossRef] [PubMed] 
66. Zhang, L.Q.; Yen, Y.; Zheng, Y.L.; Liu, D.C. Meiotic restriction in emmer wheat is controlled by one or more nuclear genes that continue to function in derived lines. Sex. Plant Reprod. 2007, 20, 159-166. [CrossRef]

67. Oleszczuk, S.; Grzechnik, N.; Mason, A.S.; Zimny, J. Heritability of meiotic restitution and fertility restoration in haploid triticale. Plant Cell Rep. 2019, 38, 1515-1525. [CrossRef]

68. Zhang, L.Q.; Liu, D.C.; Zheng, Y.L.; Yan, Z.H.; Dai, S.F.; Li, Y.F.; Jiang, Q.; Ye, Y.Q.; Yen, Y. Frequent occurrence of unreduced gametes in Triticum turgidum-Aegilops tauschii hybrids. Euphytica 2010, 172, 285-294. [CrossRef]

69. Silkova, O.G.; Loginova, D.B.; Volodina, E.A.; Ivanova, Y.N.; Bondarevich, E.B.; Solovey, L.A.; Sycheva, E.; Dubovets, N.I. Development and Characterization of Wheat-rye Hybrids Produced by Meiotic Restitution. Russ. J. Genet. 2018, 54, $1266-1276$.

70. Feldman, M.; Levy, A.A. Allopolyploidy-a shaping force in the evolution of wheat genomes. Cytogenet Genome Res. 2005, 109, 250-258. [CrossRef]

71. Silkova, O.G.; Dobrovolskaya, O.B.; Dubovets, N.I.; Adonina, I.G.; Kravtsova, L.A.; Shchapova, A.I.; Shumny, V.K. Production of wheat-rye substitution lines based on winter rye cultivars with karyotype identification by means of C-banding, GISH, and SSR markers. Rus. J. Genet. 2007, 43, 957-960. [CrossRef]

72. Badaeva, E.D.; Badaev, N.S.; Gill, D.S.; Filatenko, A.A. Intraspecific karyotype divergence in Triticum araraticum (Poaceae). Plant Syst. Evol. 1994, 192, 117-145. [CrossRef]

73. Badaeva, E.D. "Chromosomal passport" of Triticum aestivum L. em Thell. cv. Chinese Spring and standartization of chromosomal analysis of cereals. Cereal Res. Commun. 1990, 18, 273-281.

74. Gill, B.S.; Kimber, G. The Giemsa C-Banded Karyotype of Rye homoeologous/constitutive heterochromatin/chromosomes. Proc. Nat. Acad. Sci. USA 1974, 71, 1247-1249. [CrossRef] [PubMed]

75. Qi, L.L.; Wu, J.J.; Friebe, B.; Qian, C.; Gu, Y.Q.; Fu, D.L.; Gill, B.S. Sequence organization and evolutionary dynamics of Brachypodium specific centromere retrotransposons. Chromosome Res. 2013, 21, 507-521. [CrossRef] [PubMed]

76. Zhang, P.; Wanlong, L.; Fellers, J.; Friebe, B.; Gill, B.S. BAC-FISH in wheat identifies chromosome landmarks consisting of different types of transposable elements. Chromosoma 2004, 112, 288-299. [CrossRef] [PubMed]

77. Francki, M.G. Identification of Bilby, a diverged centromeric T1-copia retrotransposon family from cereal rye (Secale cereale L.). Genome 2001, 44, 266-274. [CrossRef] [PubMed]

78. Brownfield, L.; Köhler, C. Unreduced gamete formation in plants: Mechanisms and prospects. J. Exp. Bot. 2011, 62, 1659-1668. [CrossRef]

79. De Storme, N.; Geelen, D. Sexual polyploidization in plants-cytological mechanisms and molecular regulation. New Phytol. 2013, 198, 670-684. [CrossRef]

80. Mason, A.S.; Pires, J.C. Unreduced gametes: Meiotic mishap or evolutionary mechanism? Trends Genet. 2015, 31, 5-10. [CrossRef] [PubMed]

81. Shchapova, A.I.; Kravtsova, L.A.; Potapova, T.A. Patterns in the transformation of the genomic structure of wheat-rye polyhaploids ABDR. Genetica 1987, 23, 295-302.

82. Oleszczuk, S.; Rabiza-Swider, J.; Zimny, J.; Lukaszewski, A.J. Aneuploidy among androgenic progeny of hexaploid triticale (XTriticosecale Wittmack). Plant Cell Rep. 2011, 30, 575-586. [CrossRef]

83. Ishii, T.; Karimi-Ashtiyani, R.; Houben, A. Haploidization via Chromosome Elimination: Means and Mechanisms. Annu. Rev. Plant Biol. 2016, 67, 421-438. [CrossRef]

84. Nakajima, G. Occurrence of a haploid in Triticum turgidum. Jpn. J. Genet. 1935, 11, 246-247. [CrossRef]

85. Gaines, E.F.; Aase, H.C. A haploid wheat plant. AJB 1926, 13, 373-385. [CrossRef]

86. Barclay, I.R. High frequencies of haploid production in wheat (Triticum aestivum) by chromosome elimination. Nature 1975, 256, 410-411. [CrossRef]

87. Zenkteler, M.; Straub, J. Cytoembryogical studies on the process of fertilization and the development of haploid embryos of Triticum aestivum L. $(2 \mathrm{n}=42)$ after crossing with Hordeum bulbosum $(2 \mathrm{n}=14)$. Z Pflanzenzüchtg 1979, 82, 36-44.

88. Kasha, K.J.; Kao, K.N. High frequency haploid production in barley (Hordeum vulgare L.). Nature 1970, 225, 874-876. [CrossRef]

89. Ho, K.M.; Kasha, K.J. Genetic control of chromosome elimination during haploid formation in barley. Genetics 1975, 81, 263-275. [CrossRef]

90. Subrahmanyam, N.C. Haploidy from Hordeum interspecific crosses: I. Polyhaploids of H. parodii and H. procerum. Theor. Appl. Genet. 1977, 49, 209-217. [CrossRef]

91. Polgári, D.; Cseh, A.; Szakács, É.; Jäger, K.; Molnár-Láng, M.; Sági, L. High-frequency generation and characterization of intergeneric hybrids and haploids from new wheat-barley crosses. Plant Cell Rep. 2014, 33, 1323-1331. [CrossRef]

92. Polgári, D.; Mihók, E.; Sági, L. Composition and random elimination of paternal chromosomes in a large population of wheat $\times$ barley (Triticum aestivum L. $\times$ Hordeum vulgare L.) hybrids. Plant Cell Rep. 2019, 38, 767-775. [CrossRef]

93. Inagaki, M.N.; Mujeeb-Kazi, A. Comparison of polyhaploid production frequencies in crosses of hexaploid wheat with maize, pearl millet and sorghum. Breed. Sci. 1995, 45, 157-161.

94. Gernand, D.; Rutten, T.; Varshney, A.; Rubtsova, M.; Prodanovic, S.; Brüss, C.; Kumlehn, J.; Matzk, F.; Houben, A. Uniparental chromosome elimination at mitosis and interphase in wheat and pearl millet crosses involves micronucleus formation, progressive heterochromatinization, and DNA fragmentation. Plant Cell 2005, 17, 2431-2438. [CrossRef]

95. Komeda, N.; Chaudhary, H.K.; Suzuki, G.; Mukai, Y. Cytological evidence for chromosome elimination in wheat $\times$ Imperata cylindrica hybrids. Genes Genet. Syst. 2007, 82, 241-248. [CrossRef] [PubMed] 
96. Ishii, T.; Ueda, T.; Tanaka, H.; Tsujimoto, H. Chromosome elimination by wide hybridization between Triticeae or oat plant and pearl millet: Pearl millet chromosome dynamics in hybrid embryo cells. Chromosome Res. 2010, 18, 821-831. [CrossRef]

97. Zhang, J.; Yang, F.; Jiang, Y.; Guo, Y.; Wang, Y.; Zhu, X.; Li, J.; Wan, H.; Wang, Q.; Deng, Z.; et al. Preferential Subgenome Elimination and Chromosomal Structural Changes Occurring in Newly Formed Tetraploid Wheat-Aegilops ventricosa Amphiploid (AABBDvDvNvNv). Front. Genet. 2020, 11, 330. [CrossRef] [PubMed]

98. Comai, L. The advantages and disadvantages of being polyploid. Nat. Rev. Genet. 2005, 6, 836-846. [CrossRef] [PubMed]

99. Comai, L.; Tyagi, A.P.; Lysak, M.A. FISH analysis of meiosis in Arabidopsis allopolyploids. Chromosome Res. 2003, 11, 217-226. [CrossRef] [PubMed]

100. Mestiri, I.; Chagué, V.; Tanguy, A.M.; Huneau, C.; Huteau, V.; Belcram, H.; Coriton, O.; Chalhoub, B.; Jahier, J. Newly synthesized wheat allohexaploids display progenitor-dependent meiotic stability and aneuploidy but structural genomic additivity. New Phytol. 2010, 186, 86-101. [CrossRef] [PubMed]

101. Li, H.; Wang, Y.J.; Guo, X.X.; Du, Y.P.; Wang, C.Y.; Ji, W.Q. Chromosomal structural changes and microsatellite variations in newly synthesized hexaploid wheat mediated by unreduced gametes. J. Genet. 2016, 95, 819-830. [CrossRef] [PubMed]

102. Zhao, L.; Xie, D.; Fan, C.; Zhang, S.; Huang, L.; Ning, S.; Jiang, B.; Zhang, L.; Yuan, Z.; Liu, D.; et al. Chromosome Stability of Synthetic-Natural Wheat Hybrids. Front. Plant Sci. 2021, 12, 654382. [CrossRef] [PubMed]

103. Chester, M.; Gallagher, J.P.; Symonds, V.V.; Cruz da Silva, A.V.; Mavrodiev, E.V.; Leitch, A.R.; Soltis, P.S.; Soltis, D.E. Extensive chromosomal variation in a recently formed natural allopolyploid species, Tragopogon miscellus (Asteraceae). Proc. Natl. Acad. Sci. USA 2012, 109, 1176-1181. [CrossRef] [PubMed]

104. Weimarck, A. Elimination of wheat and rye chromosomes in a strain of octoploid Trit icale as revealed by Giemsa banding technique. Hereditas 1974, 77, 281-286. [CrossRef] [PubMed]

105. Shkutina, F.M.; Khvostova, V.V. Cytological investigation of Triticale. Theor. Appl. Genet. 1971, 41, 109-119. [CrossRef]

106. Lukaszewski, A.J.; Gustafson, J.P. Cytogenetics of triticale. Plant Breed. 1987, 5, 41-93.

107. Sanei, M.; Pickering, R.; Kumke, K.; Nasuda, S.; Houben, A. Loss of centromeric histone H3 (CENH3) from centromeres precedes uniparental chromosome elimination in interspecif ic barley hybrids. Proc. Natl. Acad. Sci. USA 2011, 108, E498-E505. [CrossRef]

108. Evtushenko, E.V.; Lipikhina, Y.A.; Stepochkin, P.I.; Vershinin, A.V. Cytogenetic and molecular characteristics of rye genome in octoploid triticale ( $\times$ Triticosecale Wittmack). Comp. Cytogenet. 2019, 13, 423-434. [CrossRef]

109. Devos, K.M.; Atkinson, M.D.; Chinoy, C.N.; Francis, H.A.; Harcourt, R.L.; Koebner, R.M.; Liu, C.J.; Masojć, P.; Xie, D.X.; Gale, M.D. Chromosomal rearrangements in the rye genome relative to that of wheat. Theor. Appl. Genet. 1993, 85, 673-680. [CrossRef]

110. Lukaszewski, A.J.; Gustafson, J.P.; Apolinarska, B. Transmission of Chromosomes through the Eggs and Pollen of Triticale $\mathrm{x}$ Wheat F1 Hybrids. Theor. Appl. Genet. 1982, 63, 49-55. [CrossRef]

111. Merker, A. The genome in wheat breeding. Hereditas 1984, 100, 183-191. [CrossRef]

112. Kalinka, A.; Achrem, M. Reorganization of wheat and rye genomes in octoploid triticale ( $\times$ Triticosecale). Planta 2018, 247, 807-829. [CrossRef] [PubMed]

113. Szakacs, E.; Molnar-Lang, M. Molecular cytogenetic evaluation of chromosome instability in Triticum aestivum-Secale cereale disomic addition lines. J. Appl. Genet. 2010, 51, 149-152. [CrossRef] [PubMed]

114. Szakacs, E.; Schneider, A.; Rakszegi, M.; Molnar-Lang, M. Addition of chromosome 4R from Hungarian rye cultivar Lovászpatonai confers resistance to stripe rust and outstanding end-use quality in wheat. J. Cereal Sci. 2016, 71, 204-206. [CrossRef]

115. An, D.; Ma, P.; Zheng, Q.; Fu, S.; Li, L.; Han, F.; Han, G.; Wang, J.; Xu, Y.; Jin, Y.; et al. Development and molecular cytogenetic identification of a new wheat-rye $4 \mathrm{R}$ chromosome disomic addition line with resistances to powdery mildew, stripe rust and sharp eyespot. Theor. Appl. Genet. 2019, 132, 257-272. [CrossRef]

116. Miller, T.E. The homoeologous relationship between the chromosomes of rye and wheat. Current status. Can. J. Genet. Cytol. 1984, 26, 578-589. [CrossRef]

117. Khalil, H.B.; Ehdaeivand, M.R.; Xu, Y.; Laroche, A.; Gulick, P.J. Identification and characteri zation of rye genes not expressed in allohexaploid triticale. BMC Genom. 2015, 16, 281. [CrossRef]

118. Silkova, O.G.; Adonina, I.G.; Krivosheina, E.A.; Shchapova, A.I.; Shumny, V.K. Chromosome pairing in meiosis of partially fertile wheat/rye hybrids. Plant Reprod. 2013, 26, 33-41. [CrossRef]

119. Magnard, J.-L.; Yang, M.; Chen, Y.C.S.; Leary, M.; McCormick, S. The Arabidopsis gene tardy asynchronous meiosis is required for the normal pace and synchrony of cell division during male meiosis. Plant Physiol. 2001, 127, 1157-1166. [CrossRef]

120. Wang, Y.; Magnard, J.L.; McCormick, S.; Yang, M. Progression through meiosis I and meiosis II in Arabidopsis anthers is regulated by an A-type cyclin predominately expressed in prophase I. Plant Physiol. 2004, 136, 4127-4135. [CrossRef]

121. D’Erfurth, I.; Cromer, L.; Jolivet, S.; Girard, C.; Horlow, C.; Sun, Y.; To, J.P.; Berchowitz, L.E.; Copenhaver, G.P.; Mercier, R. The cyclin-A CYCA1;2/TAM is required for the meiosis I to meiosis II transition and cooperates with OSD1 for the prophase to first meiotic division transition. PLoS Genet. 2010, 6, e1000989. [CrossRef] [PubMed]

122. Hao, M.; Luo, J.; Zeng, D.; Zhang, L.; Ning, S.; Yuan, Z.; Yan, Z.; Zhang, H.; Zheng, Y.; Feuillet, C.; et al. QTug.sau-3B is a major quantitative trait locus for wheat hexaploidization. G3: Genes Genomes Genet. 2014, 15, 1943-1953. [CrossRef] [PubMed]

123. D'Erfurth, I.; Jolivet, S.; Froger, N.; Catrice, O.; Novatchkova, M.; Mercier, R. Turning meiosis into mitosis. PLoS Biol. 2009, 7, e1000124. [CrossRef] [PubMed]

124. Wang, Y.; Jha, A.K.; Chen, R.; Doonan, J.H.; Yang, M. Polyploidy-associated genomic instability in Arabidopsis thaliana. Genesis 2010, 48, 254-263. [CrossRef] [PubMed] 
125. Qi, F.; Zhang, F. Cell Cycle Regulation in the Plant Response to Stress. Front. Plant Sci. 2020, 10, 1765. [CrossRef]

126. Rice, A.; Glick, L.; Abadi, S.; Einhorn, M.; Kopelman, N.M.; Salman-Minkov, A.; Mayzel, J.; Chay, O.; Mayrose, I. The Chromosome Counts Database (CCDB)-A community resource of plant chromosome numbers. New Phytol. 2015, 206, 19-26. [CrossRef]

127. Hardion, L.; Verlaque, R.; Rosato, M.; Rosselló, J.A.; Vila, B. Impact of polyploidy on fertility variation of Mediterranean Arundo, L. (Poaceae). C R Biol. 2015, 338, 298-306. [CrossRef] [PubMed]

128. Bowers, J.E.; Paterson, A.H. Chromosome number is key to longevity of polyploid lineages. New Phytol. 2021, 231, 19-28. [CrossRef]

129. Cheng, F.; Mandakova, T.; Wu, J.; Xie, Q.; Lysak, M.A.; Wang, X.W. Deciphering the diploid ancestral genome of the mesohexaploid Brassica rapa. Plant Cell 2013, 25, 1541-1554. [CrossRef]

130. Wang, X.Y.; Jin, D.C.; Wang, Z.Y.; Guo, H.; Zhang, L.; Wang, L.; Li, J.P.; Paterson, A.H. Telomere-centric genome repatterning determines recurring chromosome number reductions during the evolution of eukaryotes. New Phytol. 2015, 205, 378-389. [CrossRef]

131. Schubert, I.; Vu, G.T.H. Genome stability and evolution: Attempting a holistic view. Trends Plant Sci. 2016, 21, 749-757. [CrossRef]

132. Hudakova, S.; Kunzel, G.; Endo, T.R.; Schubert, I. Barley chromosome arms longer than half of the spindle axis interfere with nuclear divisions. Cytogenet. Genome Res. 2002, 98, 101-107. [CrossRef] [PubMed]

133. Hidalgo, O.; Pellicer, J.; Christenhusz, M.; Schneider, H.; Leitch, A.R.; Leitch, I.J. Is There an Upper Limit to Genome Size? Trends Plant Sci. 2017, 22, 567-573. [CrossRef] [PubMed] 